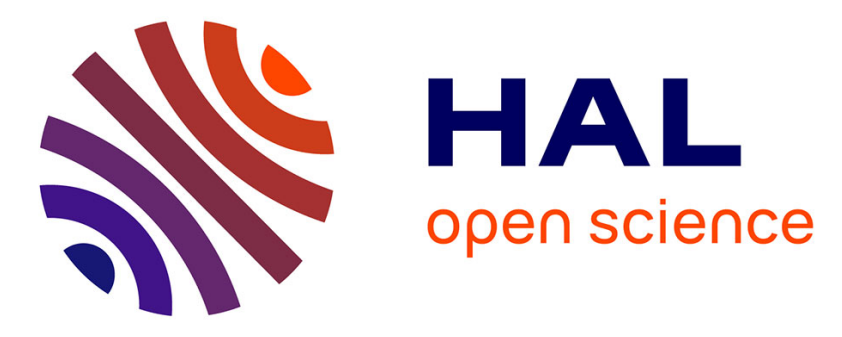

\title{
Chemistry of a series of aluminum-modified polysilazanes: Synthesis, pyrolysis behaviour and microstructural evolution
}

Chrystelle Salameh, Samuel Bernard, Christel Gervais, Florence Babonneau, Alina Bruma, Sylvie Malo, Philippe Miele

\section{To cite this version:}

Chrystelle Salameh, Samuel Bernard, Christel Gervais, Florence Babonneau, Alina Bruma, et al.. Chemistry of a series of aluminum-modified polysilazanes: Synthesis, pyrolysis behaviour and microstructural evolution. Journal of the European Ceramic Society, 2019, 39 (2-3), pp.183-194. 10.1016/j.jeurceramsoc.2018.09.027 . hal-01944455

\section{HAL Id: hal-01944455 \\ https://hal.umontpellier.fr/hal-01944455}

Submitted on 24 Jan 2020

HAL is a multi-disciplinary open access archive for the deposit and dissemination of scientific research documents, whether they are published or not. The documents may come from teaching and research institutions in France or abroad, or from public or private research centers.
L'archive ouverte pluridisciplinaire HAL, est destinée au dépôt et à la diffusion de documents scientifiques de niveau recherche, publiés ou non, émanant des établissements d'enseignement et de recherche français ou étrangers, des laboratoires publics ou privés. 


\title{
Chemistry of a series of aluminum-modified polysilazanes: synthesis, pyrolysis behaviour and microstructural evolution
}

\author{
Chrystelle Salameh $^{\mathrm{a} *}$, Samuel Bernard ${ }^{\mathrm{a}, 1}$, Christel Gervais ${ }^{\mathrm{b}, \mathrm{d}}$, Florence Babonneau ${ }^{\mathrm{b}}$, Alina \\ Bruma $^{\mathrm{c}, 2}$, Sylvie Malo ${ }^{\mathrm{c}}$, Philippe Miele $\mathrm{a}^{\mathrm{a} \mathrm{d}^{*}}$ \\ ${ }^{a}$ IEM ((Institut Européen Des Membranes), UMR 5635 (CNRS-ENSCM-UM), Université \\ Montpellier Place Eugène Bataillon, F-34095 Montpellier, France \\ ${ }^{b}$ Sorbonne Universités, UPMC, Univ. Paris 6, CNRS, Collège de France, UMR 7574, Chimie \\ de la Matière Condensée de Paris, 75005 Paris, France \\ ${ }^{c}$ Laboratoire de Cristallographie et Sciences des Matériaux (CRISMAT), UMR 6508 \\ (Normandie Univ. ENSICAEN, UNICAEN, CNRS), 14000 Caen, France \\ ${ }^{d}$ Institut Universitaire de France (IUF), MENESR, 1 rue Descartes, 75231 Paris Cedex 05 \\ *Corresponding authors Emails : chrystelle.salameh@enscm.fr \\ philippe.miele@umontpellier.fr

\footnotetext{
${ }^{1}$ Present address: Univ. Limoges, CNRS, IRCER, UMR 7315, F-87000, Limoges, France.

${ }^{2}$ Present address: Institute of Research in Electronics and Applied Physics (IREAP), University of Maryland College Park, 8279 Paint Branch Drive, College Park, MD, 20740, USA.
}

\begin{abstract}
A series of polyaluminosilazanes was synthesized by reaction of dimethylethylamine alane complex with polysilazanes. Starting from different dichlorosilanes, polysilazanes were obtained by means of ammonolysis. The latter reacted with the alane complex and led to solid polyaluminosilazanes that can be described as "custom-made" polymers since all the steps were monitored and controlled (from the choice of the molecular precursor to the polymerization and the functionalization with aluminum) in order to study the effect of the introduction of $\mathrm{Al}$ on the different reactive sites of the $\mathrm{Si}$ - backbone in the polysilazanes. Detailed information on the polymers structures were obtained by FTIR and multinuclear solid state NMR spectroscopies. The transition from the polymeric state to the ceramic inorganic state was investigated by means of solid-state NMR spectroscopy and finally the
\end{abstract}


structural evolution of the final ceramics by high angle XRD, Raman spectroscopy and TEM imaging. It is noted that the polymer-derived SiAlCN ceramics are X-ray amorphous even at high temperature under nitrogen with some local crystallization. Upon further heating these materials tend to further crystallize into thermodynamically stable phases at a given chemical composition, such as $\mathrm{SiC}, \mathrm{Si}_{3} \mathrm{~N}_{4}$, free C, or AlN. Finally, the present study shows that the amorphous-to-crystalline transition is closely related to the nature and structure of the preceramic polymer.

\section{Introduction}

Many of the important technologies such as micro-electromechanical systems, micro-sensors, 3D printed compounds, fibers, membranes and coatings depend on the successful design of inorganic components ${ }^{1,2,3,4,5,6,7}$. Indeed, simple inorganic materials present important limitations for high-temperature applications, particularly when corrosion and oxidation resistance, mechanical performance and shape design are required. The use of advanced ceramics that generally meet these requirements emphasizes the reliability of these materials for high chemical resistance and maintained mechanical properties at elevated temperatures. However, ceramics are difficult to handle owing to their intrinsically brittle behaviour, while the use of metals is limited by their intrinsic corrosion problems and by reduced performance at temperatures approaching their melting point. Moreover, the former cannot be easily shaped and manufactured. Therefore, the need for ceramics able to be tailored ondemand and perform in harsh environments is crucial. To provide this reliability, the material must have a well-defined organization of the microstructure regarding the ratio, the distribution and the properties of the constituent phases involved. Consequently, novel polymer-derived ceramics (PDCs) can be processed in order to overcome the drawbacks. The PDCs route is an attractive approach for the production of 
advanced pure ceramic materials and offers significant benefits over conventional ceramic processing techniques ${ }^{8,9,10,11,12}$. The chemistry at atomic scale (composition, structure, and homogeneity), the processing properties as well as the chemical and thermal reactivity of the polymers can be tuned to deliver, after shaping and pyrolysis, nonoxide ceramics with the desired compositional phase distribution, homogeneity and shape. This approach is applied for the elaboration of carbides, nitrides of many groups and transition elements ${ }^{13,14,15,16,17,18,19,20,21}$ as well as homogeneous mixtures or solid solutions of pseudo-binary combinations of ceramics and nanocomposites ${ }^{22,23,24}$. In particular, $\mathrm{SiCN}$ materials combine partly the properties of $\mathrm{SiC}$ and $\mathrm{Si}_{3} \mathrm{~N}_{4}$ in one material and have shown recently strong interest for environmental and "green" technologies due to their outstanding properties such as high thermal robustness, high mechanical strength, low bulk density, high thermal conductivity, high corrosion and oxidation resistance ${ }^{25,26}$. The addition of Al to silicon-based ceramics advantageously contributes to the improvement of the hydrothermal stability of the derived materials. As an illustration, the addition of $\mathrm{Al}$ to silicon oxynitrides forming $\mathrm{SiAlON}^{27}$ results in an improved thermal and chemical stability in oxidizing atmosphere, in the presence of water vapour and corrosion species which is not the case of SiON ceramics. Moreover, as demonstrated by An et $a .^{28}$ and Wang et $a l .{ }^{29}$ the addition of Al to silicon carbonitride in flowing air results in a non-parabolic oxidation curve (at $\mathrm{T} \geq 1000^{\circ} \mathrm{C}$ ) which decreases more rapidly with time, down to a negligible level. The authors suggested that the remarkably low oxidation rates of these materials are attributed to the lower permeability of the formed oxide layer to molecular oxygen, due to the incorporation of $\mathrm{Al}$ in the silica network. The passivation layer is shown to hinder diffusion-controlled oxidation in the bulk which will protect the material from oxidation. In fact, the presence of 1 to $10 \mathrm{wt} \%$ of $\mathrm{AlN}$ in $\mathrm{SiC}$ ceramics results in a fine- 
grained uniform microstructure with a potential improvement of the mechanical properties ${ }^{30}$. More reports have shown that SiAlCN ceramics own a superior creep resistance, improved oxidation and corrosion resistance and also a better thermal conductivity in comparison to $\mathrm{Al}$-free $\mathrm{Si} / \mathrm{C}$ and $\mathrm{Si} / \mathrm{C} / \mathrm{N}$ systems ${ }^{31,32,33,34,35,36,37}$. Recently, Ma et al. ${ }^{38}$ reported the preparation of polymer-derived SiAlCN ceramics by pyrolysis of an Alcontaining precursor synthesized by mixing liquid polysilazane, aluminum-tri-sec-butoxide and dicumyl peroxide. Authors showed that such materials exhibit an enhanced AC conductivity with the increase of the temperature and frequency which results in a typical NTC behavior. Also David et al. ${ }^{39}$ showed that adding Al to $\mathrm{Si} / \mathrm{C} / \mathrm{N}$ system improves the electrical conductivity and have proven that SiAlCN/CarbonNanotubes shell-core composites can be successfully used as battery electrodes. As a consequence, Polymer-Derived SilicoAluminum CarboNitride $(\mathrm{SiAlCN})$ ceramics are considered as promising candidates for high-temperature and harsh environment applications.

Two general techniques can be investigated for the synthesis of SiAlCN precursors: i) "Building block" approach or co-pyrolysis of homogeneous mixtures of polymers in a common solvent, leading to the stable phases which constitute the composite (organosilicon and organoaluminum precursors) $)^{40}$; ii) "Single source precursor" approach in which $\mathrm{Al}$ and $\mathrm{Si}$ are precombined in a common structure. Several SiAlCN polymeric precursors were reported such as $\left[\left(\mathrm{Me}_{3} \mathrm{Si}\right)_{2} \mathrm{AlNH}\right]_{2}{ }_{2}^{41},\left(\mathrm{Et}_{2} \mathrm{AlNH}_{2}\right)_{3}{ }^{42}$ that led to the highest SiAlCN yield. Janik et al. prepared solid solutions of AlN and $\mathrm{SiC}$ at temperatures $<900{ }^{\circ} \mathrm{C}$ from tris(trimethylsilyl)aluminum $\left(\left(\mathrm{Me}_{3} \mathrm{Si}\right)_{3} \mathrm{Al}\right)$ and ammonia ${ }^{43}$. Boury et al. demonstrated that SiAlCN ceramics could be obtained with high ceramic yield through the reaction between $\left[\mathrm{CH}_{3} \mathrm{Si}(\mathrm{H}) \mathrm{NH}\right]_{\mathrm{n}}$ with $\left(\mathrm{CH}_{3}\right)_{3} \mathrm{Al}$ or $\left(\mathrm{CH}_{3}\right)_{2} \mathrm{AlNH}_{2}{ }^{44}$. In addition, the synthesis of SiAlCN from commercial polysilazane namely polyureamethylvinylsilazane (Ceraset $\left.{ }^{\circledR}\right)$ that reacted with an aluminum isopropoxide has been reported ${ }^{45}$. The formation of 
polyaluminosilazane results from a reaction between the $\mathrm{N}-\mathrm{H}$ units of Ceraset and Al-O units of the aluminum isopropoxide. The authors provided a detailed characterization of the polymer-to-ceramic transformation by means of FTIR and NMR spectroscopies and they revealed the effect of $\mathrm{Al}$ content on the structural behavior of the material. Three stages were observed when it comes to the polymer-to-ceramic conversion: i) cross-linking reaction forming $\mathrm{SiC}_{3} \mathrm{~N}$ units, ii) thermal decomposition forming $\mathrm{SiCN}_{3}$ units and iii) structural rearrangement resulting in the formation of $\mathrm{AlN}_{5} / \mathrm{AlN}_{6}$. Müller and co-workers ${ }^{46}$ prepared polyaluminosilazanes from polysilazanes and polysilylcarbodiimides by means of hydroalumination of vinyl substituents at $\mathrm{Si}$ and subsequent dehydrocoupling of $\mathrm{N}-\mathrm{H}$ reactive sites. Based on the multinuclear solid-state NMR $\left({ }^{1} \mathrm{H},{ }^{13} \mathrm{C},{ }^{27} \mathrm{Al}\right.$, and $\left.{ }^{29} \mathrm{Si}\right), \mathrm{EPR}$ and FTIR techniques, they investigated the structural evolution of the preceramic polymer. The latter transforms into an amorphous preceramic network around $500^{\circ} \mathrm{C}$ where $\mathrm{AlN}$ and $\mathrm{SiCN}$ clusters are formed. Above this temperature a complete transformation into an amorphous ceramic, characterized by the presence of a $\mathrm{Si} / \mathrm{C} / \mathrm{N}$ matrix (i.e., $\mathrm{SiC}_{\mathrm{x}} \mathrm{N}_{4-\mathrm{x}}$ with $\mathrm{x}=0,1,2,4$ ), amorphous (graphite-like) carbon, and $\mathrm{AlN}_{\mathrm{x}}$ domains with $\mathrm{Al}$ in different coordination spheres $(\mathrm{x}=4,5,6)$, takes place. This amorphous state remains up to $1400^{\circ} \mathrm{C}$.

The $\mathrm{Si} / \mathrm{Al} / \mathrm{C} / \mathrm{N}$ system represents a ceramic material with an amorphous structure made of covalent bonds that is stable at high temperatures. The development of SiAlCN ceramics from single source precursors is a very interesting approach because of the ability to: i) control the composition of polymers and derived ceramics at the atomic scale, ii) introduce attached functional groups or substituents that are reactive sites which are beneficial for the shaping ability of the polymer as well as their pyrolysis behavior, and iii) determine the functionality of the derived ceramics. For example, $\mathrm{SiCH}=\mathrm{CH}_{2}, \mathrm{SiH}$ and $\mathrm{NH}$ groups, due to their chemical reactivity, offer the opportunity to attach supplementary elements to the polymer structure. Aluminum can be introduced by hydroalumination of $\mathrm{CH}=\mathrm{CH}_{2}$ groups, using alane Lewis- 
base adducts. Accordingly, the molecular weights of the polymers may be increased via hydrosilylation $\left(\mathrm{SiH}+\mathrm{SiCHCH}_{2}\right)$. Reactions may involve dehydrocoupling with formation of $\mathrm{Si}-\mathrm{N}$ units $(\mathrm{SiH}+\mathrm{NH})$. Individual steps of the procedure to prepare polymer-derived $\mathrm{SiAlCN}$ ceramics were carefully investigated. In particular, we describe the synthesis of a series of polyaluminosilazanes by reaction of ammonia (=network building agent) with dichlorosilanes followed by a reaction with an alane complex. As-obtained polyaluminosilazanes were structurally characterized then pyrolyzed at $1000^{\circ} \mathrm{C}$ under nitrogen to deliver amorphous SiAlCN materials. A systematic mechanistic study of the polymer-to-ceramic conversion of the polyaluminosilazanes in nitrogen atmosphere is provided. The individual chemical processing steps and the related structural and chemical changes occurring during the polymer-to-ceramic conversion were investigated in details using ex-situ solid-state NMR and FTIR spectroscopies. Then, more structural investigations are reported to follow the evolution of the amorphous SiAlCN network into a multiphase component made of $\mathrm{SiC}, \mathrm{Si}_{3} \mathrm{~N}_{4}, \mathrm{AlN}$ and free carbon. The four single-source precursors investigated display different reactive sites that will affect the polymerization mechanisms and thus the ceramic yield and eventually the shaping abilities of the polymers. For instance, polysilazanes containing vinyl/allyl groups will react with $\mathrm{AlH}_{3}$ via different mechanisms and cross-linking degrees during the hydroalumination. Whereas the presence of $\mathrm{Si}-\mathrm{H}$ groups will show possible coupling reactions that can occur during the polymerization.

\section{Experimental}

\subsection{Materials}

All the synthesis procedures have been performed using the Schlenk technique operating with an argon/vacuum line in order to prevent contamination of the synthesized products with oxygen and moisture. Argon was purified by passing through successive columns of 
phosphorus pentoxide siccapent ${ }^{\mathrm{TM}}$, and BTS catalysts. All the Schlenk tubes and glassware were dried at $120^{\circ} \mathrm{C}$ prior to use. The chemicals were handled in an MBraun, M200B glovebox operating under argon with a rate of $\mathrm{O}_{2}$ and $\mathrm{H}_{2} \mathrm{O}<0.1$ ppm. Dichloromethylvinylsilane and dicholoromethylsilane were purchased from Sigma-Aldrich, whereas dichloroallylsilane and dichlorodivinylsilane were purchased from ABCR chemicals. Toluene $(99.85 \%$, extra-dry over molecular sieve, AcroSeal®) was obtained from Acros Organics. N,N dimethylethylaminealane complex $0.5 \mathrm{M}$ in toluene was provided by SigmaAldrich.

2.2 Synthesis of polyaluminosilazanes-derived SiAlCN ceramics

In order to purify the precursors, dichlorocarbosilanes illustrated in Figure 1, were freshly distilled with magnesium powders. Dichloromethylvinylsilane was freshly distilled at $110-115^{\circ} \mathrm{C}$, dichloromethylsilane at $45-50^{\circ} \mathrm{C}$, dichloroallylsilane at 110 $115^{\circ} \mathrm{C}$ and dichlorodivinylsilane at $120-150^{\circ} \mathrm{C}$.

The preparation of poly(methylvinyl)aluminosilazane is described below as a representative procedure, since the other precursors were prepared similarly. In details, a three necked Schlenk tube was equipped with a water cooled reflux condenser and a gas inlet tube. $35 \mathrm{~g}(0.25 \mathrm{~mol})$ of dichloromethylvinylsilane were dissolved in $500 \mathrm{~mL}$ of toluene. The system was cooled at $0^{\circ} \mathrm{C}$ and ammonia (at $-40^{\circ} \mathrm{C}$ ) was slowly added. After the addition was finished, the solution was warmed naturally to room temperature and the by-products were separated by filtration through a pad of Celite. Once a clear solution was obtained, the solvent was removed by distillation under vacuum (RT/10 ${ }^{-2}$ mbar). Polymethyvinylsilazane was obtained as a transparent viscous liquid. The quantity of ammonia is not a key point in the control of the polycarbosilazane's structure; therefore an excess of ammonia was used and the quantity was controlled through the condensation of ammonia in the condenser after 
bubbling into the chlorosilane solution. $40 \mathrm{~mL}(20 \mathrm{mmol})$ of solution of $\mathrm{AlH}_{3} \cdot \mathrm{N}(\mathrm{Me})_{2} \mathrm{Et}$ in toluene were added at $0^{\circ} \mathrm{C}$ to $5 \mathrm{~g}(58.7 \mathrm{mmol})$ of polymethylvinylsilazane in solution with $200 \mathrm{~mL}$ of toluene. After three days of stirring, the by-products were eliminated by filtration and the solvent removed by distillation at $\left(\mathrm{RT} / 10^{-2}\right)$ and $3.5 \mathrm{~g}(70 \%$ yield) of Al- modified polymethyvinylsilazane was obtained, a moisture- and air-sensitive white polymer we labelled PMVAZ.

The details concerning the synthesis of the different PolyAluminoSilaZanes (PASZs) are reported in Table 1. PMAZ (derived from dichloromethylsilane), PMVAZ (derived from dichloromethylvinylsilane), PAAZ (derived from dichloroallylsilane), PDVAZ (derived from dichlorodivinylsilane) refer respectively to Poly-Methyl-AluminosilaZane, PolyMethylVinyl-AluminosilaZane, Poly-Allyl-AluminosilaZane and Poly-DiVinylAluminosilaZane.<smiles>C=C[Si](C)(Cl)O[Mg][Mg]</smiles>
(PMVAZ precursor)<smiles>C=CC[SiH](Cl)Cl</smiles>

Dichloroallylsilane

(PAAZ precursor)<smiles>C[SiH](Cl)Cl</smiles>

Dichloromethylsilane (PMAZ precursor)<smiles>C=C[Si](Cl)(Cl)C=C</smiles>

Dichlorodivinylsilane (PDVAZ precursor)

Figure 1 : Molecular structures of the dichlorocarbosilanes used.

As-synthesized polymers are all in form of white glass-like powders very sensitive to air and moisture. The structure of the different polymers was investigated by FTIR and solid-state NMR spectroscopies. 
For each thermolysis experiment, PASZs were introduced into a nitrogen-filled glove box connected to a horizontal tube furnace (Nabertherm type RS 80/500/11, Germany). The powder samples were put into an alumina boat and then introduced into the furnace. The tube was evacuated $\left(10^{-3} \mathrm{mbar}\right)$ and refilled with nitrogen $(99.995 \%)$. Subsequently, samples are subjected to a cycle of ramping of $5^{\circ} \mathrm{C} \cdot \mathrm{min}^{-1}$ to $1000^{\circ} \mathrm{C}$ and annealed at this temperature for $2 \mathrm{~h}$ in flowing nitrogen $\left(120 \mathrm{~mL} \cdot \mathrm{min}^{-1}\right)$. The samples were finally cooled to RT at $5^{\circ} \mathrm{C} \cdot \mathrm{min}^{-1}$. Nitrogen-treated materials were further heattreated in a nitrogen atmosphere up to $1800^{\circ} \mathrm{C}\left(5^{\circ} \mathrm{C} \cdot \mathrm{min}^{-1}\right)$ and held $2 \mathrm{~h}$ at the final temperature in the range $1200-1800^{\circ} \mathrm{C}$ in a graphitic furnace (Gero, Model HTK8).

Table 1 : Synthesis data of the polyaluminosilazanes (PASZs).

\begin{tabular}{lllllll}
\hline PASZ & Name & Dichlorosilane & $\begin{array}{l}\text { M polycarbo- } \\
\text { silazane } \\
\mathbf{g}(\mathbf{m m o l})\end{array}$ & $\begin{array}{l}\text { V } \\
\mathbf{A l H}_{\mathbf{3}} \cdot \\
\mathbf{N}(\mathbf{M e})_{2} \mathbf{E t} \\
\mathbf{m L}(\mathbf{m m o l})\end{array}$ & $\begin{array}{l}\text { M } \\
\text { PASZ } \\
\mathbf{g}\end{array}$ & $\begin{array}{l}\text { Synthesis } \\
\text { yield \% }\end{array}$ \\
& & & & $75(37.5)$ & 5 & 77 \\
\hline PMAZ & PolyMethylAluminosilaZane & Dichloromethylsilane & $6.5(109)$ & $70(20)$ & 3.5 & 70 \\
\hline PMVAZ & PolyMethylVinylAluminosilaZane & Dichloromethylvinylsilane & $5(58.7)$ & $65(32.5)$ & 8 & 100 \\
\hline PAAZ & PolyAllylAluminosilaZane & Dichloroallylsilane & $8(94)$ & 650 & 66 \\
\hline PDVAZ & PolyDiVinylAluminosilaZane & Dichlorodivinylsilane & $8(82)$ & $60(30)$ & 5.28 & 6 \\
\hline
\end{tabular}

\subsection{Characterization techniques}

FTIR was performed on a Nicolet Magna-IR 550 Fourier transformspectrophotometer 5 Nicolet Instrument Co. USA) using $\mathrm{KBr}$ pellets (2 wt\% of polymer mixed with previously dried $\mathrm{KBr}$ powder followed by a compaction into a dense pellet). Preparation of samples for analyses has been done in a glove box filled with argon.

${ }^{13} \mathrm{C},{ }^{29} \mathrm{Si}$ and ${ }^{15} \mathrm{~N}$-solid-state NMR spectra were recorded with a Bruker AVANCE 300 spectrometer using a $7 \mathrm{~mm}$ Bruker probe and spinning frequencies of $5 \mathrm{kHz} .{ }^{27} \mathrm{Al}$ solid-state NMR spectra were recorded on both Bruker AVANCE 500 and 700 spectrometers using 4 and $3.2 \mathrm{~mm}$ Bruker probes and spinning frequencies of 14 and $20 \mathrm{kHz}$ respectively. Chemical shift values were referenced to tetramethylsilane for ${ }^{13} \mathrm{C}$ 
and ${ }^{29} \mathrm{Si}, \mathrm{CH}_{3} \mathrm{NO}_{2}$ for ${ }^{15} \mathrm{~N}$ and $\mathrm{Al}\left(\mathrm{NO}_{3}\right)_{3}$ for ${ }^{27} \mathrm{Al}$. Spectra were simulated with the DMFIT program ${ }^{47}$.

As-pyrolyzed samples were characterized by X-ray diffraction (Philips PW 3040/60 X'pert PRO X-ray diffraction system operating at $30 \mathrm{~mA}$ and $40 \mathrm{kV}$ from 10 to $90^{\circ}$ with a step size of 0.0167 , using a Kal of copper as source), Raman spectroscopy (A Renishaw model RM 1000 Raman operating at $\lambda \sim 514.5 \mathrm{~nm}$ ). The microstructural evolution of SiAlCN derived from PMVAZ (PMVAZ-d-SiAlCN) was investigated by TEM measurements (FEI Tecnai G2 30 UT operating at $300 \mathrm{kV}$ ). The chemical composition of the SiAlCN materials was obtained by EDX (microanalysis system with IDFix and MaxViwe softwares from SamX coupled to a Hitashi S800 microscope).

\section{Results and discussion}

\subsection{Synthesis of polyaluminosilazanes}

The Al-modified polycarbosilazanes, called polyaluminosilazanes (PASZs), were prepared via a "polymer" route according to a procedure described for the synthesis of boron-modified poly(vinylsilazanes) $)^{48}$. Precursor synthesis was performed by ammonolysis of commercial dichlorocarbosilanes, followed by a reaction with the alane complex in toluene solution. During the first step (ammonolysis), the majority of $\mathrm{Si}-\mathrm{Cl}$ groups are converted into $\mathrm{Si}-\mathrm{NH}_{2}$ by reaction of dichlorosilanes with excess of ammonia. The resulting $\mathrm{Si}-\mathrm{NH}_{2}$ groups polycondense at $\mathrm{RT}$ to build up the polycarbosilazane network through Si-NH-Si units, according to the ideal synthesis pathway depicted in Figure 2 releasing ammonium chloride. 


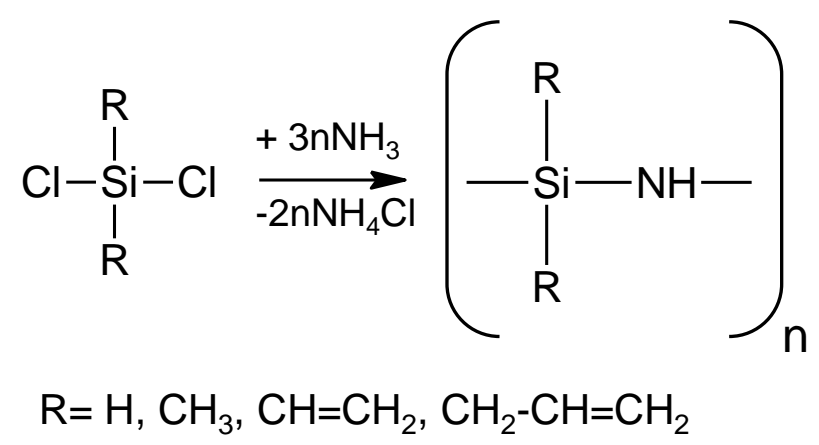

Figure 2 : Ammonolysis of dichlorocarbosilanes.

In a second step, addition of the alane complex $\mathrm{AlH}_{3} \cdot \mathrm{N}(\mathrm{Me})_{2} \mathrm{Et}$ on the polycarbosilazanes occurs. Based on the synthesis of boron- modified polycarbosilazanes for which hydroboration is reported ${ }^{49}$, we expected hydroalumination reactions between the vinyl/allyl groups in the polycarbosilazane obtained from the four different dichlorosilanes and the Al- $\mathrm{H}$ units of the alane complex. According to the presence of $3 \mathrm{Al}-\mathrm{H}$ bonds in the alane, 3 vinyl or allyl groups should react with the alane complex $\left(3 \mathrm{CH}_{2}=\mathrm{CH}-\mathrm{Si}+\mathrm{AlH}_{3} \rightarrow \mathrm{Al}\left(\mathrm{C}_{2} \mathrm{H}_{4} \mathrm{Si}\right)_{3}\right)$. This corresponds, ideally, to a $\mathrm{Si}: \mathrm{Al}$ ratio of 3 . This is why we used this ratio in our experimental protocol. However, Berger et $a .^{46}$ reported that hydroalumination reactions are incomplete and are accompanied by dehydrocoupling reactions. Therefore, we have considered a last sample prepared without vinyl/allyl groups from the dichloromethylsilane to identify this reaction.

The structure of the polymers was analyzed using infrared spectroscopy. Figure 3 shows the spectra for the four synthesized polyaluminosilazanes. The band characteristic of $\mathrm{N}-\mathrm{H}$ bonds $\left(v_{\mathrm{N}-\mathrm{H}}=3450 \mathrm{~cm}^{-1}\right)$ is, as expected not intense, indicating a possible dehydrocoupling reaction involving $\mathrm{NH}$ groups in PMVZ and $\mathrm{AlH}$ units in the alane complex forming Al-N bonds. This is confirmed through the presence of the band around $1753 \mathrm{~cm}^{-1}$ which is attributed to the vibration of Al-N bonds. The bands in the wavenumber range $3365-3385 \mathrm{~cm}^{-1}$ and 1375 $\left(\delta_{\mathrm{sCH} 3}\right)-1450\left(\delta_{\mathrm{asCH} 3}\right) \mathrm{cm}^{-1}$ are broad which is due to the incorporation of carbon-based groups 
in PMVAZ. The low intensity of the band attributed to vinyl groups $\left(1650-1600 \mathrm{~cm}^{-1}\right)$ tends to demonstrate the occurrence of hydroalumination reactions. The region $1200-500 \mathrm{~cm}^{-1}$ is difficult to interpret in PMVAZ. All the polyaluminosilazanes display a weak absorption signal in the $3365-3385 \mathrm{~cm}^{-1}$ region, and the series of bands in the wavenumber range 2750 $3100 \mathrm{~cm}^{-1}$, which confirms the presence of N-H and C-H vibrational bands, respectively. In addition, they exhibit the bands around $1753 \mathrm{~cm}^{-1}$ caused by the vibration of Al-N bonds and the bands ascribed to $\mathrm{Si}-\mathrm{N}$ vibrations that appear in the $1190-1200 \mathrm{~cm}^{-1}$ range. We can also observe the band at $1650 \mathrm{~cm}^{-1}$ which is present in the vinyl-/allyl- containing polycarbosilazanes. This means that hydroalumination occurs but is not total. Particularly, in the PMAZ and PAAZ spectra we can detect the vibrational $\mathrm{Si}-\mathrm{H}$ band at 2159 and $2124 \mathrm{~cm}^{-1}$, respectively, it seems that the dehydrocoupling is significantly favored for PMAZ. Consequently, a steric effect can be identified. The highly sterical allyl groups in PAAZ, in comparison to methyl groups in PMAZ, hinder an easy access to $\mathrm{Si}-\mathrm{H}$ groups leading thus to a less extent of the coupling reactions as compared to PMAZ. It should be mentioned that in the case of PAAZ, the concurrence between hydroalumination and dehydrocoupling might significantly decrease the occurrence of dehydrocoupling reactions. Furthermore, it seems that the extent of dehydrocoupling is higher in PDVAZ than in PMAZ. Finally, a comparison of PMVAZ with PMAZ makes clear that hydroalumination is a concurrent reaction to dehydrocoupling. For all polymers, we can detect a band around $2100 \mathrm{~cm}^{-1}$ attributed to Al$\mathrm{H}$ vibrations from the residual alane complex. In the case of PMAZ and PAAZ, the shape of the signal indicates that there are two overlapping absorption bands, therefore Al-H vibrations are assigned along with $\mathrm{Si}-\mathrm{H}$ bands around $2100 \mathrm{~cm}^{-1}$. Deformation bands of $\mathrm{CH}_{3}$ appear for all samples: $\delta_{\mathrm{sCH} 3}=1375 \mathrm{~cm}^{-1}$ and $\delta_{\mathrm{asCH} 3}=1450 \mathrm{~cm}^{-1}$. Based on the infrared spectroscopy, we can suggest that hydroalumination of the vinyl/allyl groups takes place but, according to the 
identification of Al-N bonds, dehydrocoupling reactions also proceed as reported by Berger et $a l .{ }^{46}$. However, we cannot state which reaction is preferred without additional information.

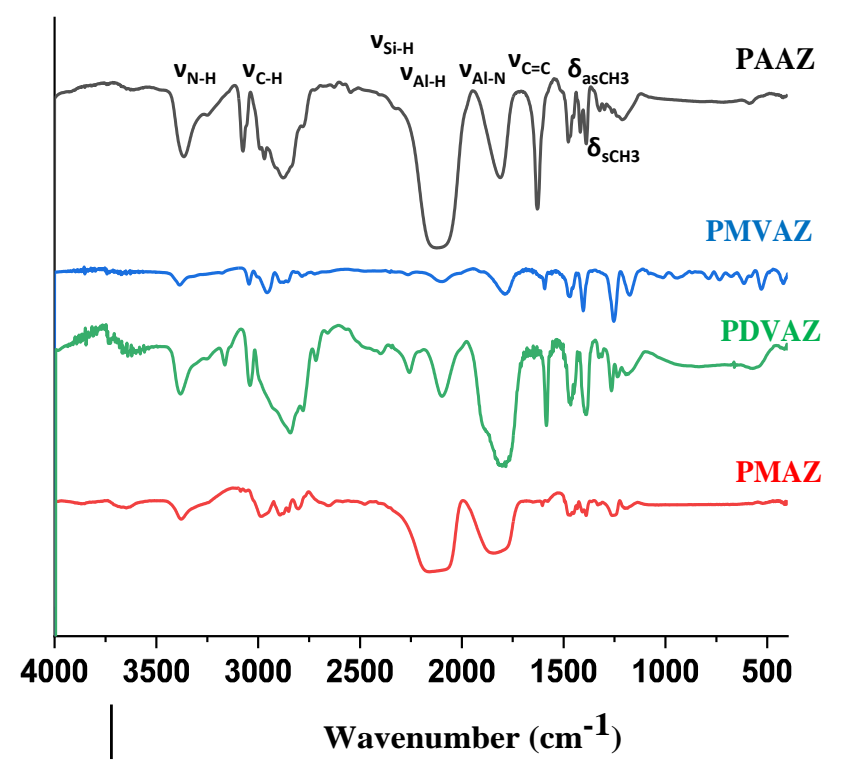

Figure 3 : FTIR spectra of PAAZ, PMVAZ, PDVAZ and PMAZ.

Solid-state NMR was used to confirm these hypotheses. This technique is of particular interest for complex systems such as ternary $(\mathrm{Si} / \mathrm{C} / \mathrm{N})$ and quaternary ceramic systems ( $\mathrm{Si} / \mathrm{B} / \mathrm{C} / \mathrm{N}, \mathrm{Si} / \mathrm{Al} / \mathrm{C} / \mathrm{N})$, not only to establish the chemical environment of the atoms in the polymeric precursor containing various NMR-active nuclei, but also applied to the pyrolyzed intermediates to follow the structural evolution from the polymer to the ceramic. Unlike the case of $\mathrm{Si} / \mathrm{C} / \mathrm{N}$ and $\mathrm{Si} / \mathrm{B} / \mathrm{C} / \mathrm{N}$, so far only little has been investigated concerning the structural evolution of $\mathrm{Si} / \mathrm{Al} / \mathrm{C} / \mathrm{N}$ quaternary systems ${ }^{46}$. Multinuclear $\left({ }^{13} \mathrm{C},{ }^{29} \mathrm{Si},{ }^{27} \mathrm{Al},{ }^{15} \mathrm{~N}\right.$, solid-state NMR spectroscopy experiments were used to investigate the structure of aluminum-modified polysilazanes, from which SiAlCN ceramics are formed. It should be emphasized that the two-step polymer synthesis (ammonolysis and alane reaction) is expected to give rise to a large variety of structural components which are not all explicitly shown in the idealized structures/reactions discussed previously. Therefore, we will try to give a detailed 
representation of the structure of polyaluminosilazanes described in Table 1 based on the local carbon, silicon, aluminum and nitrogen environments. ${ }^{13} \mathrm{C},{ }^{29} \mathrm{Si}$ and ${ }^{27} \mathrm{Al}$ are sufficiently abundant to be studied without isotopic enrichment. Nevertheless, ${ }^{13} \mathrm{C}$ spectra were recorded using the cross-polarisation $(\mathrm{CP})$ technique to obtain spectra with reasonable signal-to-noise ratio. The experimental and simulated ${ }^{13} \mathrm{C} \mathrm{CP}$ MAS NMR spectra of four polyaluminosilazane samples are given in Figure 4.

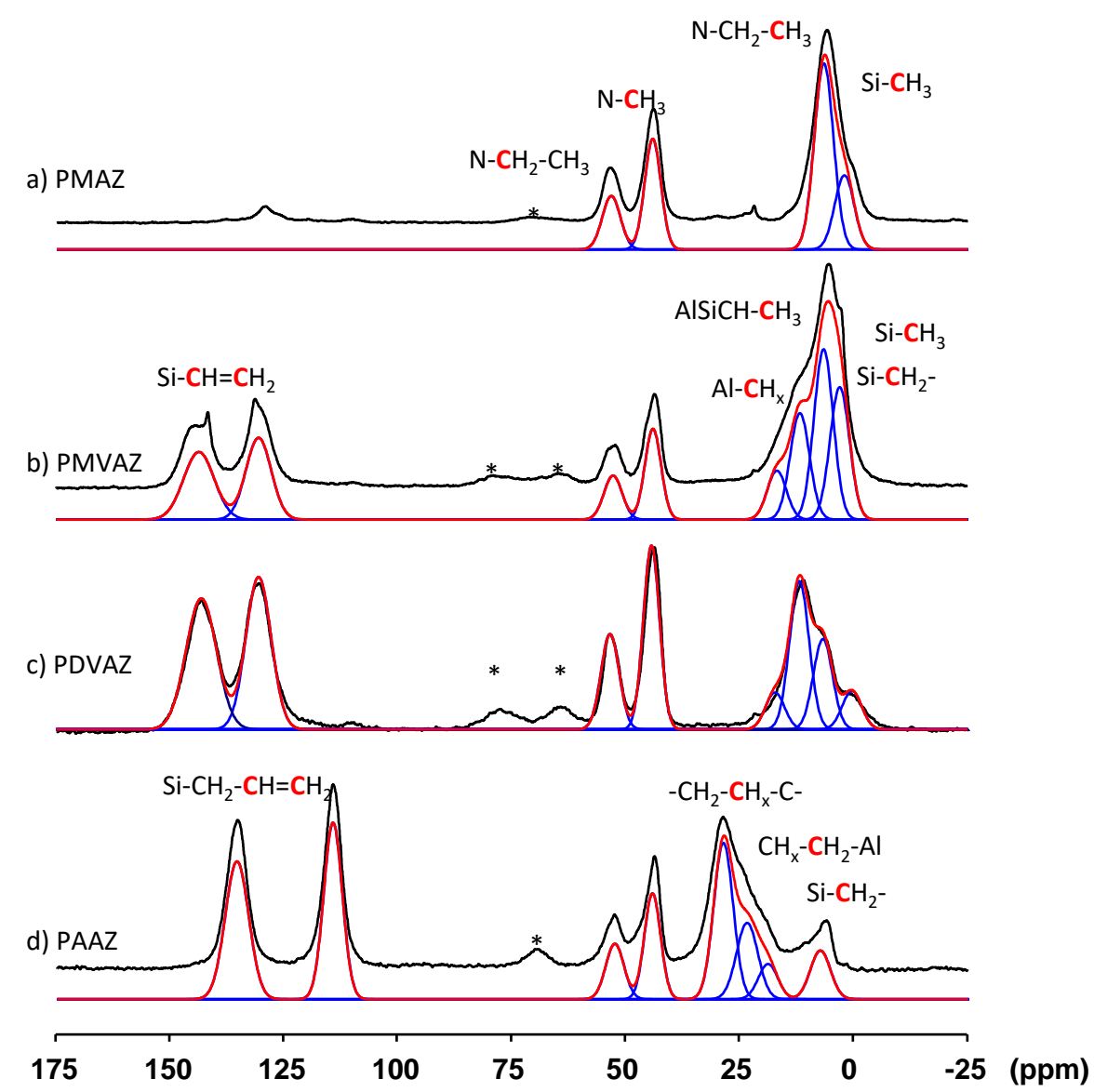

Figure $4:{ }^{13} \mathrm{C}$ CP MAS NMR experimental and simulated spectra of a) PMAZ, b)

PMVAZ, c) PDVAZ, and d) PAAZ.

We can clearly identify the signals in the range $115-150 \mathrm{ppm}$ corresponding to $s p^{2}$ carbons which are attributed to the vinyl $(131,145 \mathrm{ppm})$ and allyl $(115,137 \mathrm{ppm})$ groups $^{50}$ that did not react during the addition of aluminum in PMVAZ, PAAZ, and PDVAZ. This confirms that hydroalumination is not the only reaction that occurs during the synthesis of 
polyaluminosilazanes. These signals are logically absent in the sample PMAZ since it does not contain allyl and/or vinyl groups. All samples exhibit two signals at $\sim 53$ and $\sim 46 \mathrm{ppm}$ which are attributed to $\mathrm{N}-\mathrm{CH}_{2}-\mathrm{CH}_{3}$ and $\mathrm{NCH}_{3}$ groups coming from the alane. The PMAZ spectrum shows two other overlapping signals around 3 and 7 ppm that can be assigned to Si$\mathrm{CH}_{3}$ and $\mathrm{N}-\mathrm{CH}_{2}-\mathrm{CH}_{3}$ environments respectively. For the PMVAZ and PDVAZ, additional signals are present between 10 and $20 \mathrm{ppm}$. They most probably arise from hydroalumination reactions leading to the formation of $\mathrm{Si}-\mathrm{CH}\left(\mathrm{CH}_{3}\right)-\mathrm{Al}$ and $\mathrm{Si}-\mathrm{CH}_{2}-\mathrm{CH}_{2}-\mathrm{Al}$ units. According to previous work $^{46}$, signals around $20 \mathrm{ppm}$ could correspond to $\mathrm{Al}-\boldsymbol{C H}_{2}$ and $\mathrm{Al}-\boldsymbol{C H}$ environments while $\mathrm{Si}-\mathrm{CH}\left(\mathrm{CH}_{3}\right)-\mathrm{Al}$ is expected to be around $10 \mathrm{ppm}$. $\mathrm{Si}-\mathrm{CH}_{2}$ probably resonates in the same area as $\mathrm{Si}-\mathrm{CH}_{3}$, that is at a small chemical shift value around $5 \mathrm{ppm}$ as previously observed in $\mathrm{Si} / \mathrm{B} / \mathrm{C} / \mathrm{N}$ systems ${ }^{51}$. For PAAZ sample, signals are also present around $25 \mathrm{ppm}$ that can be assigned to the presence of $\mathrm{Si}-\mathrm{CH}_{2}-\mathrm{CH}_{2-}, \mathrm{CH}_{2}-\mathrm{Al}$ and $\mathrm{Al} / \mathrm{Si}-\mathrm{CH}\left(\mathrm{CH}_{3}\right)^{-}$ $\mathrm{CH}_{2}-\mathrm{Si} / \mathrm{Al}$ environments. The ${ }^{29} \mathrm{Si}$ MAS spectra of the polymeric precursors are shown in Figure 5. 

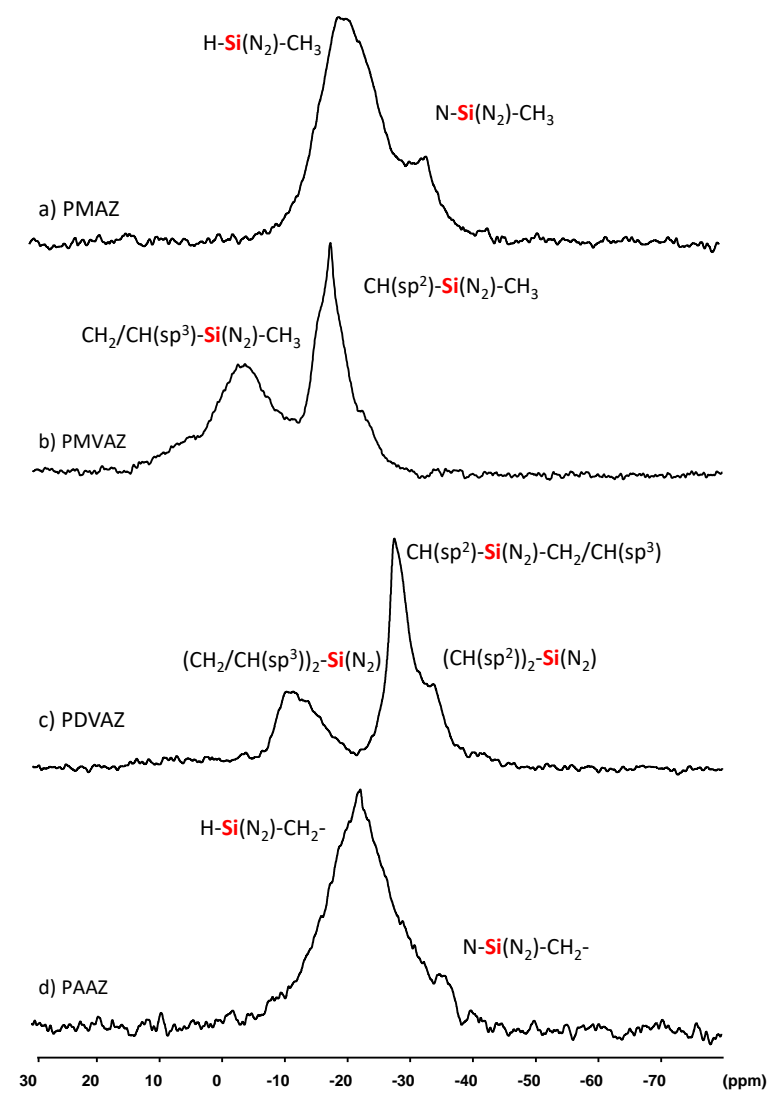

\section{Figure 5 : ${ }^{29}$ Si MAS spectra of a) PMAZ, b) PMVAZ, c) PDVAZ and d) PAAZ.}

On the PMAZ spectrum, the main signal observed at $-21 \mathrm{ppm}$ can be assigned to the expected $\mathrm{SiHCN}_{2}$ environment from the ammonolysis. Indeed, signals attributed to $\operatorname{SiHC}\left(s p^{3}\right) \mathrm{N}_{2}$ groups are usually observed at $-18 \mathrm{ppm}^{51,52,53}$. Nonetheless, an additional signal is observed at $\sim-32 \mathrm{ppm}$ that could correspond to a $\mathrm{SiN}_{3} \mathrm{C}$ environment ${ }^{54}$. This suggests a possible reaction between $\mathrm{SiH}$ units and $\mathrm{NCH}_{\mathrm{x}}$ groups present in the alane. A similar reaction has already been observed between $\mathrm{Si}-\mathrm{H}$ units of polymethylsilazane and $\mathrm{NCH}_{3}$ groups of tetrakis(dimethylamino)titanium ${ }^{55}$. These two signals are also observed for the PAAZ sample in agreement with its expected structure.

$\mathrm{SiC}_{2} \mathrm{~N}_{2}$ environments ( -5 ppm) are, as expected, present in PMVAZ and PDVAZ as classically observed in boron-modified polysilazane with $s p^{3}$ carbons ${ }^{51,52,53,56}$, confirming that hydroalumination occurs in these samples. Moreover, in PMVAZ, an additional signal is observed around - 15 ppm, a chemical shift close to the one observed in solution for $\mathrm{CH}_{2}=\mathrm{CH}$ - 
$\mathrm{SiN}_{2}-\mathrm{CH}_{3}$ units $^{57}$. This signal could therefore correspond to $\mathrm{Si}$ units bound to vinyl groups that did not react during the addition of aluminum, as observed by ${ }^{13} \mathrm{C} C P$ MAS NMR (figure 4). Similarly, the signal centered at $-28 \mathrm{ppm}$ in PDVAZ could correspond to $\mathrm{CH}\left(s p^{2}\right)-\mathrm{SiN}_{2}-$ $\mathrm{CH}_{2} / \mathrm{CH}\left(s p^{2}\right)$ units considering the sensitivity of $\mathrm{SiC}_{2} \mathrm{~N}_{2}$ chemical shift to the hybridization of the carbon in $\alpha$ position.

Figure 6 shows the ${ }^{27} \mathrm{Al}$ MAS NMR spectra of PMVAZ, PAAZ and PDVAZ samples recorded at relatively high field $(11.7 \mathrm{~T})$ since ${ }^{27} \mathrm{Al}$ is a quadrupolar nucleus $(\mathrm{I}=5 / 2)$ but very large signals are nonetheless observed, probably corresponding to overlapping features. Spectra of PMAZ and PDVAZ were recorded at higher field (16.4 T) and high spinning speed $(20 \mathrm{kHz})$ but unfortunately the resolution is not significantly improved (see Fig1 in SI.). A tentative fit of the spectra is proposed. A signal at $150 \mathrm{ppm}$ is observed in PMVAZ and PDVAZ that can be possibly assigned to $\mathrm{AlN}_{2} \mathrm{C}_{2}$ environments that have been reported between 159.5 and $148.2 \mathrm{ppm}^{58,59}$, suggesting hydroalumination reactions. Then all spectra show signals at $\approx 130 \mathrm{ppm}, \approx 80 \mathrm{ppm}, \approx 50 \mathrm{ppm}$ and a main one at $\approx 110 \mathrm{ppm}$. The latter is probably due to $\mathrm{AlN}_{4}$ sites $^{60}$ while the signal at $130 \mathrm{ppm}$ is consistent with $\mathrm{AlN}_{3} \mathrm{C}$ or $\mathrm{AlN}_{3} \mathrm{H}$ environments, the one at $\approx 80 \mathrm{ppm}$ to $\mathrm{AlN}_{4} \mathrm{C}$ or even $\mathrm{AlN}_{\mathrm{x}} \mathrm{O}_{4-\mathrm{x}}(\mathrm{x}=1,2)^{61}$. Finally, the signal at $\approx 50 \mathrm{ppm}$ is consistent with $\mathrm{AlN}_{5}{ }^{60}$ or less probably to $\mathrm{AlO}_{4}{ }^{61}$. The presence of Al-N bonds confirms dehydrocoupling reactions between $\mathrm{NH}$ of the silazane and the alane. 


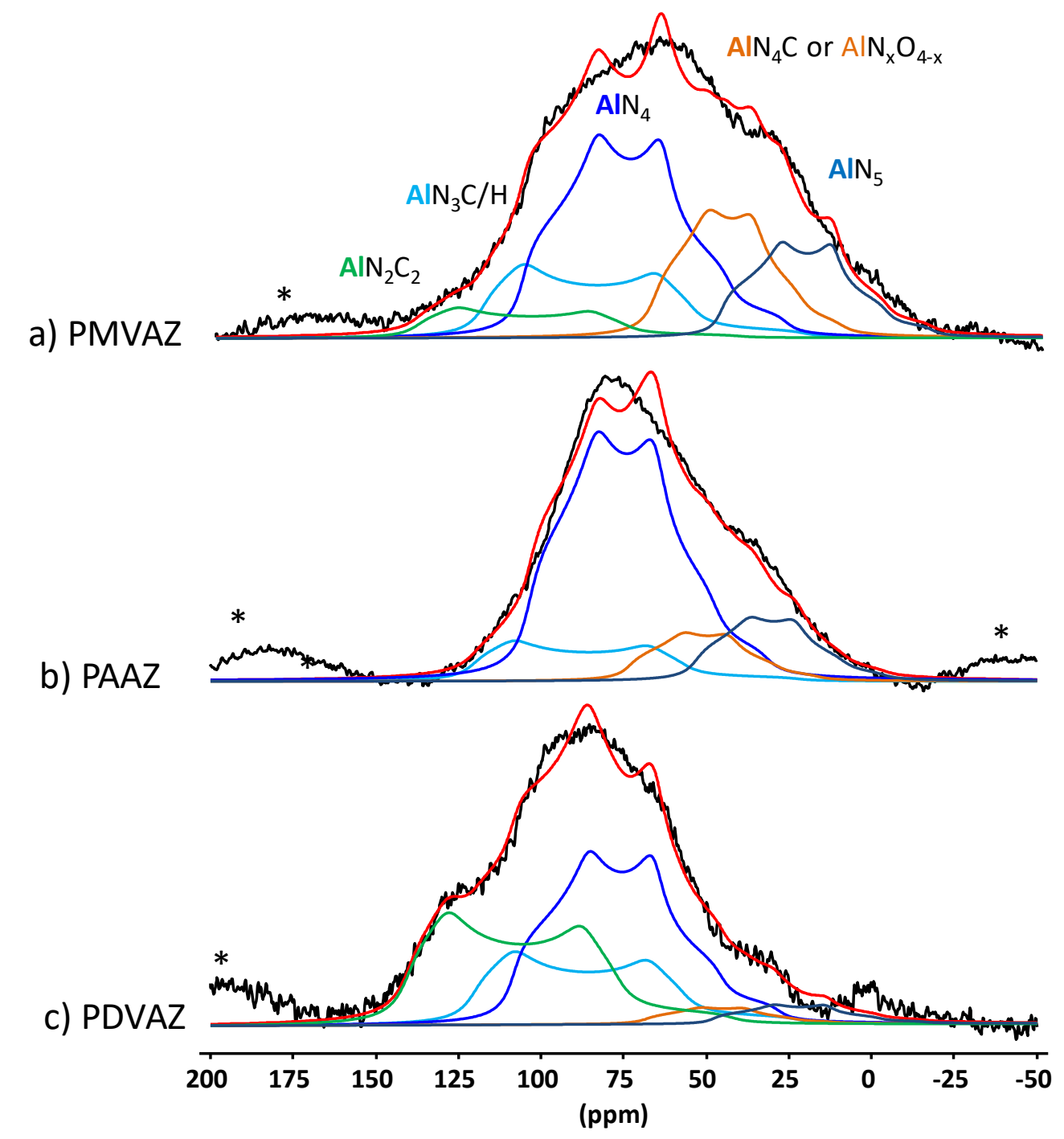

Figure 6: ${ }^{27} \mathrm{Al}$ MAS spectra of a) PMVAZ, b) PAAZ and c) PDVAZ $\left(\mathrm{B}_{0}=11.6 \mathrm{~T}\right.$, vrot $=$ $14 \mathrm{kHz}$ ). Tentative fits and assignments are proposed. (*) indicate spinning sidebands.

${ }^{15} \mathrm{~N}$ CP MAS NMR spectra (Figure 7) of the four samples exhibit at least two main signals around $-330 \mathrm{ppm}$ and $-355 \mathrm{ppm}$. The first one can be assigned to $\mathrm{HNSi}_{2}$ units of the silazane backbone while the second is tentatively assigned to $\mathrm{NCH}_{3}$ or $\mathrm{N}-\mathrm{CH}_{2}$ - environments coming from the alane ${ }^{55}$. An additional signal around $-345 \mathrm{ppm}$ is present in PMVAZ and probably PAAZ: ${ }^{15} \mathrm{~N}$ chemical shift values of $\mathrm{NAl}_{4-\mathrm{x}} \mathrm{H}_{\mathrm{x}}(\mathrm{x}=1-3)$ environments have been calculated between -330 and $-370 \mathrm{ppm}^{62}$ and could be a possible assignment. 


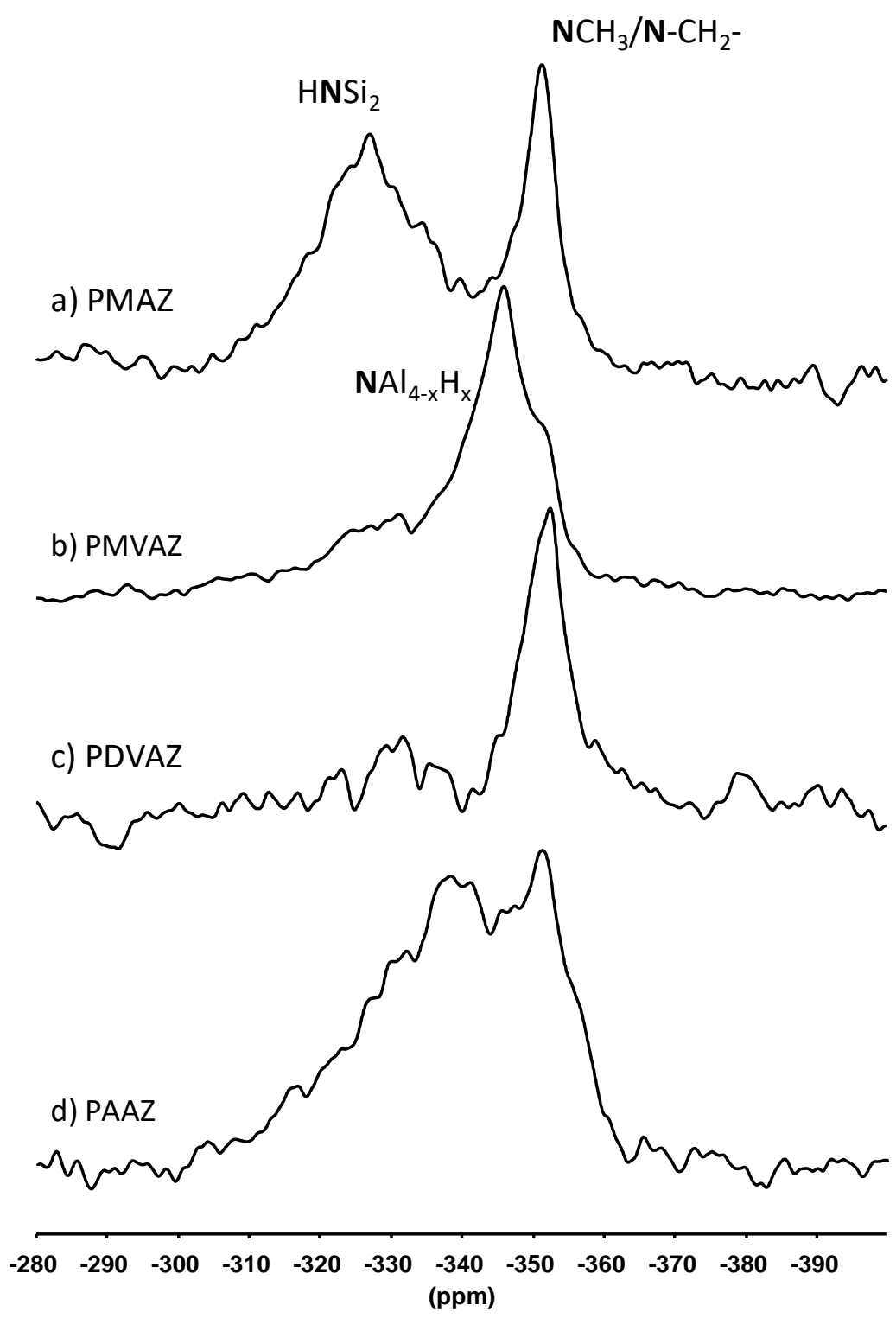

Figure $7:{ }^{15}$ N CP MAS NMR spectra of a) PMAZ, b) PMVAZ, c) PDVAZ and d) PAAZ.

Based on solid-state NMR, we identified the two possible reactions that occur during the synthesis of the polyaluminosilazanes: hydroalumination and dehydrocoupling. This indicates the strong difference in the reactivity of aluminum in comparison to boron. In boron-modified polysilazanes derived from molecular precursors, it is usually reported that hydroboration is the only mechanism that occur during the synthesis of these polymers. Such a reaction is total and no residual vinyl groups are found in boron-modified polysilazanes. However, we recently showed that in the case of boron-modified commercial poly(vinylmethyl-comethyl)silazane a competition between hydroboration and dehydrocoupling occurs depending 
on the $\mathrm{Si} / \mathrm{B}$ ratio ${ }^{63}$. The differences in the selectivity of reaction of $\mathrm{AlH}_{3}$ and $\mathrm{BH}_{3}$ with the polycarbosilazanes can be due to the different reactivity of $\mathrm{AlH}_{3}$ and $\mathrm{BH}_{3}$ towards $\mathrm{C}=\mathrm{C}$ groups and N-H functions, which can be explained by their different Lewis base acidity. Because aluminum organyles exhibit a distinguished Lewis acidity, reactions of alanes with vinyl-containing polysilazanes are thus not restricted to the hydroalumination of olefinic groups. Also, dehydrocoupling along with the formation of Al-N units takes place. According to these contrasts, the polymer-to-ceramic conversion is expected to be extremely complex in the case of SiAlCN materials.

\subsection{Polyaluminosilazanes-to-SiAlCN conversion}

The pyrolysis of the polymers was performed under $\mathrm{N}_{2}$ up to $1000^{\circ} \mathrm{C}$. The pyrolysis behavior of the preceramic polymer is intimately linked to its cross-linking degree and also to the presence of groups with a latent reactivity. Aluminum, added by hydroalumination and dehydrocoupling, contributes to increase the cross-linking degree of polycarbosilazanes (=PSZs) leading to polyaluminocarbosilazanes (=PASZs). The thermal conversion of preceramic polymers into ceramic is accompanied by the formation of gaseous by-products and therefore weight loss occurs during the polymer-to-ceramic conversion. Table 2 shows the weight loss of the polymers at different temperatures. The polymer-to-ceramic conversion was investigated by pyrolysis under $\mathrm{N}_{2}$ up to $1000^{\circ} \mathrm{C}\left(5^{\circ} \mathrm{C} \cdot \mathrm{min}^{-1}\right)$.

Table 2 : Weight loss of the PASZs at different temperatures.

\begin{tabular}{lllll}
\hline Sample & PMAZ & PMVAZ & PAAZ & PDVAZ \\
\hline Weight Loss (wt \%) & 31 & 29 & 23 & 27.5 \\
\hline
\end{tabular}

The weight loss which is intimately related to the latent thermal reactivity of the specific groups that are linked to $\mathrm{Si}$. As an illustration, PAAZ exhibits $\mathrm{Si}-\mathrm{H}$, remaining allyl groups and N-H units (because they do not react totally with the alane) as identified by FTIR and 
solid-state NMR. The cross-linking reactions are either trans-amination followed by ammonia elimination, dehydrocoupling or hydrosilylation or polymerization of vinyl/allyl groups.

Structural changes occurring during the pyrolysis up to $1000^{\circ} \mathrm{C}$ were monitored by solid-state NMR of intermediates isolated at $200,450,700$ and $1000^{\circ} \mathrm{C}$. We selected the sample PMVAZ to observe the evolution of the vinyl groups during the pyrolysis according to the absence of $\mathrm{Si}-\mathrm{H}$ units, and to follow the evolution of the chemical environment around $\mathrm{Al}$ since it is expected to be bonded to $\mathrm{C}$ and $\mathrm{N}$ elements.

\subsection{PMVAZ structure evolution: $\mathrm{RT} \rightarrow 1000^{\circ} \mathrm{C}$}

Figure 8 exhibits the ${ }^{29} \mathrm{Si}$ MAS NMR spectra of PMVAZ and of the derived $\mathrm{N}_{2}$-treated intermediates between 200 and $1000^{\circ} \mathrm{C}$. We previously discussed the ${ }^{29} \mathrm{Si}$ NMR spectrum of PMVAZ that contains broad signals corresponding to $\mathrm{SiC}_{2} \mathrm{~N}_{2}$ environments with a signal at -5 ppm and another one at $-15 \mathrm{ppm}$ due to the presence of one $s p^{2}$ carbon linked to Si. With increasing temperature, signals broaden and the spectra become featureless. After calcination at $450^{\circ} \mathrm{C}$ under $\mathrm{N}_{2}$, this broad signal is centered at $-5 \mathrm{ppm}$. Above $450^{\circ} \mathrm{C}$, the peak progressively tends to shift to lower positions while the signal is still characterized by overlapping resonances. The signal is centered at $-13 \mathrm{ppm}$ at $700^{\circ} \mathrm{C}$ and $-25 \mathrm{ppm}$ at $1000^{\circ} \mathrm{C}$. The appearance of these broadened signals is typical for amorphous Si-based PDCs ${ }^{64,10}$ and it is in general caused by overlapping resonances of $\mathrm{SiC}_{\mathrm{x}} \mathrm{N}_{4-\mathrm{x}}$ units (with $\mathrm{x}=0,1,2,3$ and 4). Moreover, $\mathrm{SiC}_{3} \mathrm{~N}$ units cannot be identified in PMVAZ-derived SiAlCN ceramics (since they are expected at positive chemical shift values) in contrast to polymer-derived SiBCN ceramics ${ }^{51}$. The sample heat-treated at $1000^{\circ} \mathrm{C}$ is composed of $\mathrm{SiC}_{2} \mathrm{~N}_{2}, \mathrm{SiCN}_{3}, \mathrm{SiC}_{4}$ and $\mathrm{SiN}_{4}$ environments expected about $-10 \mathrm{ppm},-30 \mathrm{ppm}^{54},-19 \mathrm{ppm}^{65}$ and $-48 \mathrm{ppm}^{66}$ respectively. 


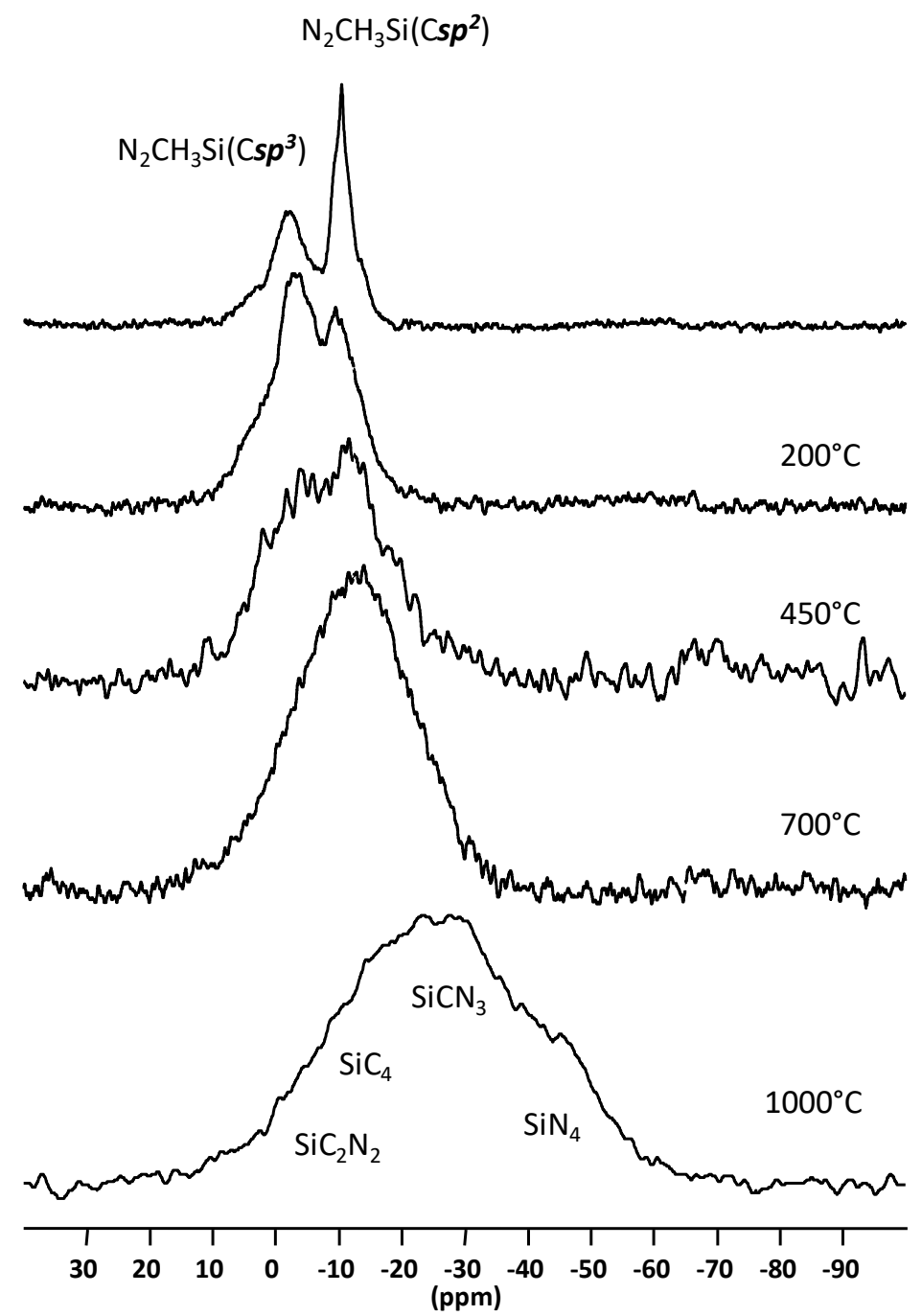

Figure $8:{ }^{29} \mathrm{Si}$ MAS spectra of PMVAZ and $\mathrm{N}_{2}$-treated intermediates at 200, 450, 700 and $1000^{\circ} \mathrm{C}$.

Experimental ${ }^{27} \mathrm{Al}$ MAS NMR spectra recorded at $11.6 \mathrm{~T}$ are presented in Figure 9. Only minor changes occur during the heat-treatment from RT to $1000^{\circ} \mathrm{C}$ essentially related to the disappearance of the signals at higher chemical shift values and therefore suggesting the disappearing of Al-C and Al-H bonds. 


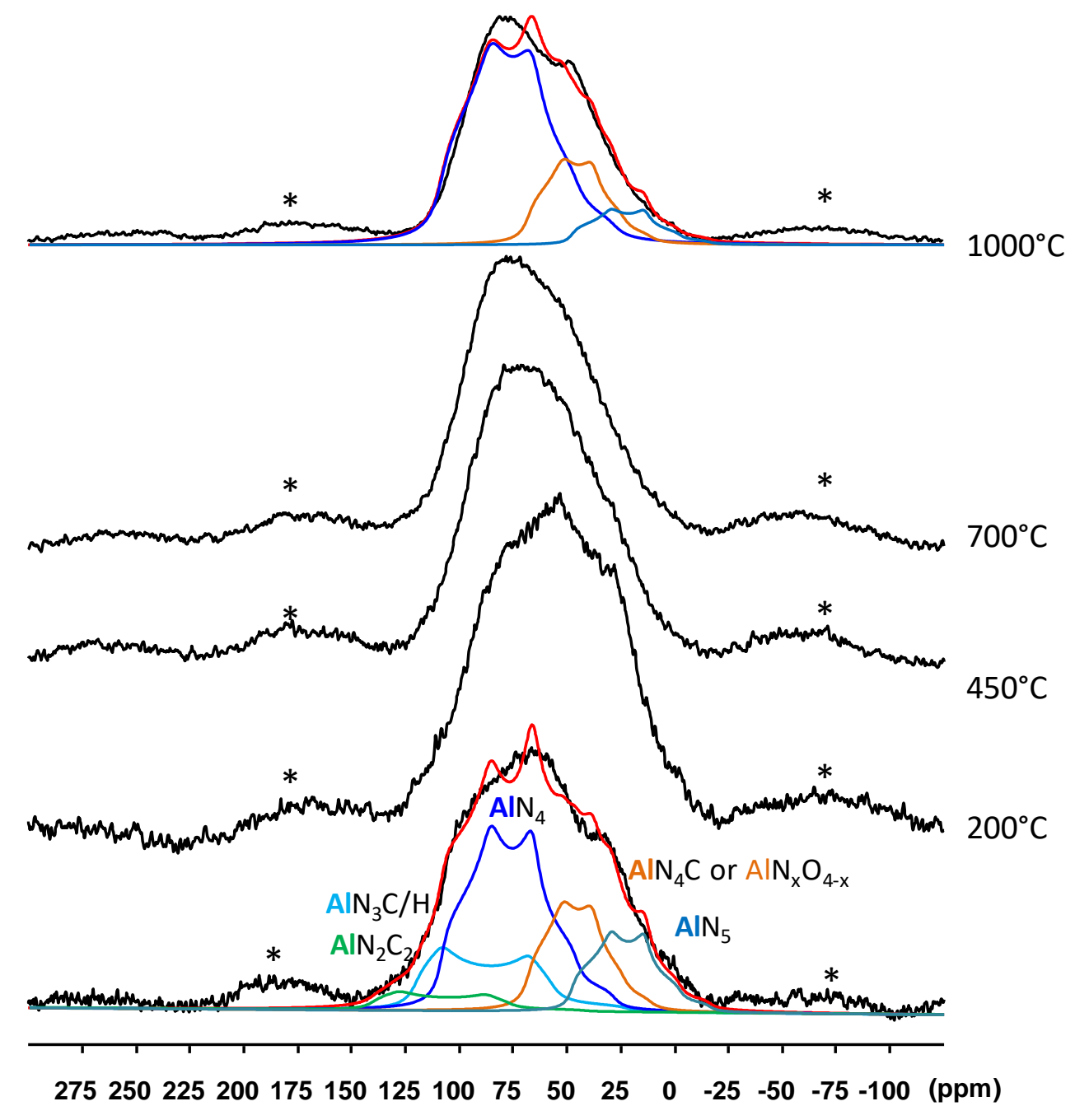

Figure $9:{ }^{27} \mathrm{Al}$ MAS spectra of PMVAZ and PMVAZ-derived samples pyrolyzed at 200, 450,700 and $1000^{\circ} \mathrm{C}$ under $\mathrm{N}_{2} .\left(B_{0}=11.6 \mathrm{~T}, v_{\text {rot }}=14 \mathrm{kHz}\right)$. Tentative fits and assignments are proposed. (*) indicate spinning sidebands.

Experimental ${ }^{13} \mathrm{C}$ CP MAS NMR spectra are given in Figure 10. The samples heat-treated at $1000^{\circ} \mathrm{C}$ could not be recorded with $\mathrm{CP}$ due to the absence of protons. As previously discussed, the PMVAZ exhibits a set of signals attributed to the vinyl groups (133 and 141 $\mathrm{ppm}$ ) that did not react during the hydroalumination, ethylamine groups (53, $46 \mathrm{ppm})$ and aliphatic groups linked to $\mathrm{Si}$ and $\mathrm{Al}$ (in the range 2-20 ppm) resulting from hydroalumination in $\alpha$ and $\beta$ position of the carbon. Heat-treatment at $200^{\circ} \mathrm{C}$ induces the disappearance of the signal in the 40-58 ppm region, confirming that they are ending groups such as amine-based 
units. The signal intensity corresponding to vinyl groups decreases pointing to a thermally induced polymerization of the Si-bonded vinyl groups and their conversion into aliphatic hydrocarbons $\left(-\mathrm{CH}_{2}-\mathrm{CH}_{2}\right)_{\mathrm{n}}$ and/or the release of ethylene/acetylene. These reactions are significant in the temperature range $200-450^{\circ} \mathrm{C}$. The signal centered at $10 \mathrm{ppm}$ does not change in intensity but has a tendency to broaden. That can be assigned to $\mathrm{CH}_{\mathrm{x}} \mathrm{Si}_{4-\mathrm{x}}$ units (with $\mathrm{x}=0,1,2)^{52,64}$. The broad signal in the low-field region at $130-140 \mathrm{ppm}$, which is more intense in the sample heat-treated at $700^{\circ} \mathrm{C}$, indicates the formation of amorphous (graphitelike) carbon during the thermal degradation.

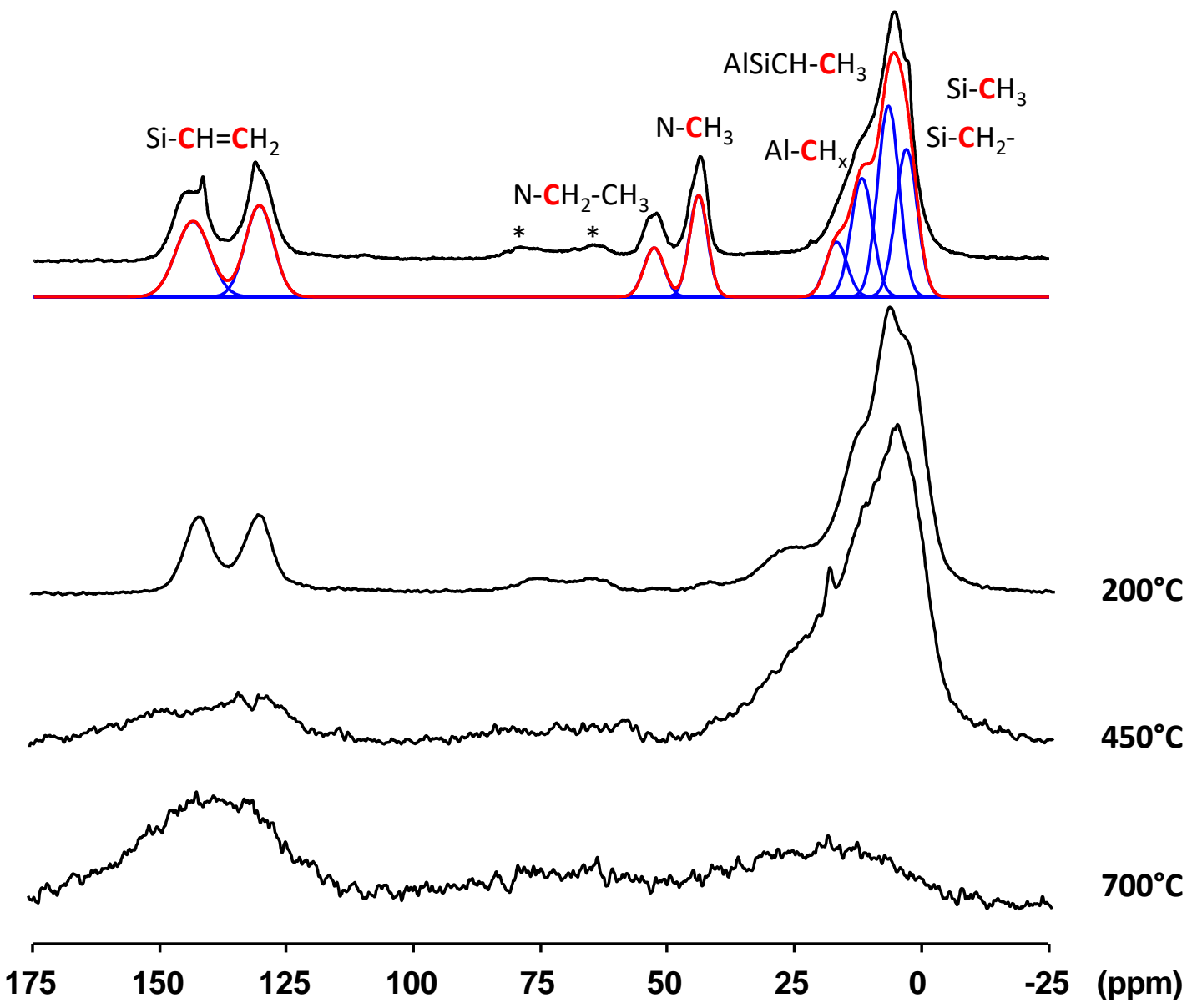

Figure $10:{ }^{13} \mathrm{C}$ CP MAS NMR spectra of PMVAZ and $\mathrm{N}_{2}$-treated intermediates at 200,

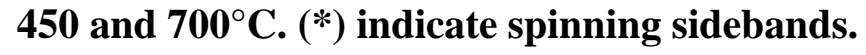

The PASZ-to-SiAlCN conversion is achieved at $1000^{\circ} \mathrm{C}$. The chemistry involved during the polymer-to-ceramic conversion is intimately related to the chemistry of the polymer, 
including the structural rearrangements at the atomic scale. In particular, the chemistry involved during the polymer-to-ceramic conversion includes a complex sequence of structural and chemical changes based on molecular rearrangements and the release of gaseous byproducts. In the following part, the amorphous-to-crystalline transformation is investigated. The introduction of boron into silicocarbonitride ceramics can lead to materials possessing excellent high-temperature stability and resistance to crystallization which was explained by the formation of a turbostratic B-C-N phase retarding the possible decomposition reactions between $\mathrm{Si}_{3} \mathrm{~N}_{4}$ and free carbon ${ }^{67}$ which is also expected with the substitution of boron by aluminum.

\subsection{Characterization of $\mathrm{SiAlCN}: 1000 \rightarrow 1800^{\circ} \mathrm{C}$}

The main purpose of producing polymers with different structural units is to tailor "ondemand" the composition and properties of the derived PDCs. The latter have a molecular origin, i.e., their properties are affected by the intrinsic architecture of the starting polymer. After heat-treatment to $1000^{\circ} \mathrm{C}$, PASZ-derived SiAlCN ceramics labelled PASZX (with X the temperature at which PASZs have been annealed) are amorphous. The general amorphous state of polymer-derived $\mathrm{SiCN}$ ceramics at $1000^{\circ} \mathrm{C}$ can be associated to a continuous network of mixed $\mathrm{SiC}_{\mathrm{x}} \mathrm{N}_{\mathrm{y}}$ environments combined with a free carbon phase ${ }^{11}$. Further annealing to temperatures exceeding $1000^{\circ} \mathrm{C}$ promotes rearrangements within the amorphous matrix. Based on TEM studies, Monthioux and Delverdier ${ }^{68}$ reported that the nucleation of the free C, commonly present in organosilicon polymer-based PDCs, is always the first crystallization phenomenon that takes place. A nucleation of the SiC phase follows this first event whatever the number of constituents within the system. For SiAlCN, there is no clear justification of this statement and we show in this study that even though the ceramic is X-ray amorphous at $1000^{\circ} \mathrm{C}$, it starts showing some crystallization as depicted by TEM. This point aims at the characterization of the chemical evolution as well as the phase evolution and crystallization of 
the amorphous PASZ-derived SiAlCN ceramics. In particular, the effect of the polymer nature and the influence of its chemistry are examined.

The elemental compositions of the PASZ-derived SiAlCN ceramics after pyrolysis at $1000^{\circ} \mathrm{C}$ are obtained by EDX and given in Table 3. As expected, the samples are composed of Si, Al, $\mathrm{C}$ and $\mathrm{N}$ with a small amount of $\mathrm{O}$.

Table 3: Elemental composition of polyaluminosilazane-derived SiAICN ceramics.*

\begin{tabular}{lllllll}
\hline Sample & $\begin{array}{l}\mathrm{Si} \\
(\mathbf{w t} \%)\end{array}$ & $\begin{array}{l}\mathrm{Al} \\
(\mathbf{w t} \%)\end{array}$ & $\begin{array}{l}\mathbf{C} \\
(\mathbf{w t} \%)\end{array}$ & $\begin{array}{l}\mathbf{N} \\
(\mathbf{w t} \%)\end{array}$ & $\begin{array}{l}\mathbf{O} \\
(\mathbf{w t} \%)\end{array}$ & $\begin{array}{l}\text { Chemical } \\
\text { composition }\end{array}$ \\
\hline PMAZ & 39 & 18 & 15 & 23 & 5 & $\mathrm{Si}_{3.0} \mathrm{Al}_{1.4} \mathrm{C}_{2.7} \mathrm{~N}_{3.5} \mathrm{O}_{0.6}$ \\
$\mathbf{1 0 0 0}$ & & & & & & \\
\hline PMVAZ & 24 & 16 & 23 & 29 & 8 & $\mathrm{Si}_{3.0} \mathrm{Al}_{2.0} \mathrm{C}_{6.7} \mathrm{~N}_{7.3} \mathrm{O}_{1.7}$ \\
$\mathbf{1 0 0 0}$ & & & & & & \\
\hline PAAZ & 32 & 12 & 29 & 19 & 8 & $\mathrm{Si}_{3.0} \mathrm{Al}_{1.2} \mathrm{C}_{6.4} \mathrm{~N}_{3.6} \mathrm{O}_{1.3}$ \\
$\mathbf{1 0 0 0}$ & & & & & & \\
\hline PDVAZ & 32 & 16 & 30 & 17 & 5 & $\mathrm{Si}_{3.0} \mathrm{Al}_{1.6} \mathrm{C}_{6.6} \mathrm{~N}_{3.2} \mathrm{O}_{0.8}$ \\
$\mathbf{1 0 0 0}$ & & & & & &
\end{tabular}

*Referenced to Si3.0 and normalized to $100 \mathrm{wt} \%$.

On the basis of our experience with the synthesis of a variety of nitrides and carbonitrides and the difficulties associated with the elemental analysis of such materials, we can assume that an oxygen content level $\leq 8 \mathrm{wt} \%$ is mainly associated with the presence of surface oxides on phase-pure nitride/carbonitrides. In addition, $\mathrm{O}$ may also result from the adhesive carbon tape used for EDX preparation. Eventhough elemental analysis were not performed on the starting PASZs due to the high sensitivity of such polymers, we can observe that the Si:Al ratio of the derived ceramics is close to 3 corresponding to the theoratical $\mathrm{Si}$ Al ratio we fixed during the synthesis of PASZs with the exception of PMVAZ1000. The low carbon content in PMAZ1000 is related to the low carbon content of the polymer $\left(1 \mathrm{CH}_{3} \mathrm{Si}\right.$ unit in the monomeric structure). For the other samples, the carbon content is similar. It is seen that the total nitrogen content remains nearly constant in all of the samples (excepted for 
PMVAZ1000) which was expected according to the fact that all polymers contain $1 \mathrm{NH}$ unit in the monomeric structure.

$\mathrm{XRD}$ diagrams of SiAlCN materials annealed at temperatures going from 1000 to $1800^{\circ} \mathrm{C}$ with an isothermal hold of $2 \mathrm{~h}$ at each temperature are reported in Figure 11. Phase identification is achieved by locating the characteristic diffraction peaks of the respective phases in the XRD patterns.
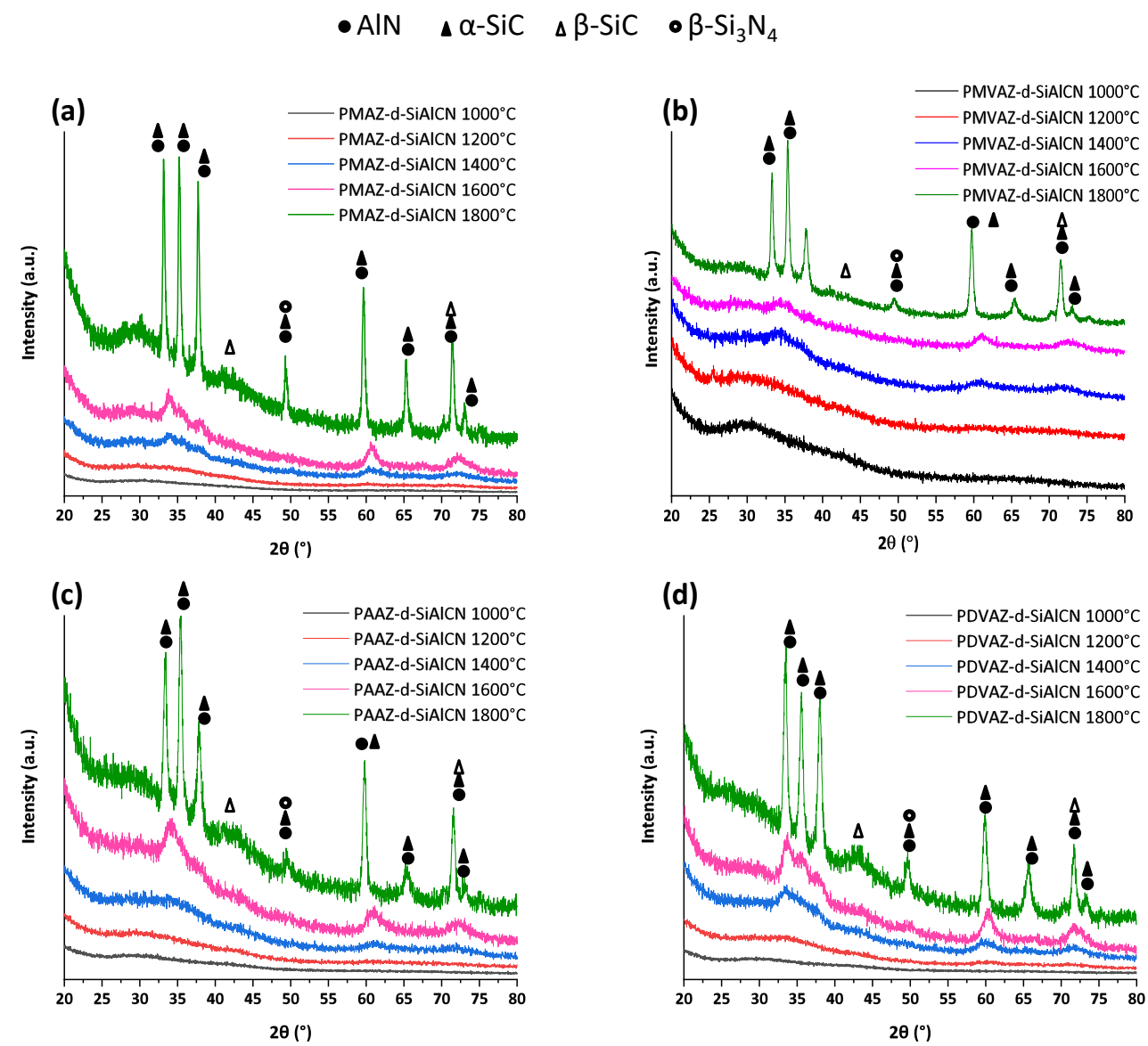

Figure 11 : XRD patterns of SiAICN materials at 1000, 1200, 1400, 1600 and $1800^{\circ} \mathrm{C}$ under $\mathrm{N}_{2}$ derived from (a) PMAZ, (b) PMVAZ, (c) PAAZ and (d) PDVAZ.

As previously discussed, PASZ-derived SiAlCN ceramics, independently from the nature of the preceramic polymer, are amorphous at $1000^{\circ} \mathrm{C}$ and remain in this state up to $1200^{\circ} \mathrm{C}$. At $1400^{\circ} \mathrm{C}$, the degree of crystallinity seems to be affected by the type of the polymeric precursor. In particular, the XRD pattern of PDVAZ1400 shows broad peaks corresponding to 
nanosized $\beta$-SiC crystals. This observation points out the fact that $\mathrm{SiC}$ nucleation already occurs at $1400^{\circ} \mathrm{C}$ if the starting polymer contains relatively high carbon units. It is interesting to observe that, at the opposite, SiAlCN ceramics derived from PMAZ (without olefin), i.e., PMAZ1400, do not show any diffraction peaks. Riedel and co-workers studied the effect of carbon content and the precursor chemistry on the crystallization of amorphous $\mathrm{SiCN}$ ceramics $^{69}$. These authors showed that the C:Si atomic ratio had an effect on the crystallization of $\mathrm{Si}_{3} \mathrm{~N}_{4}$ and no relationship with the crystallization of $\mathrm{SiC}$. In our case, it seems that the C:Si ratio measured in PASZ-derived SiAlCN ceramics has a clear effect on the structural evolution of the samples: the lowest C:Si ratio attributed to PMAZ1000 (Table 3) corresponds to the lowest degree of crystallization after annealing to $1800^{\circ} \mathrm{C}$ (PMAZ1800). This is clear based on the XRD patterns of the samples derived from PAAZ1000. The former $(\mathrm{C}: \mathrm{Si}=2.1)$ crystallizes earlier than the latter $(\mathrm{C}: \mathrm{Si}=1.5)$ upon heating to $1800^{\circ} \mathrm{C}$. As mentioned above, the sample PMAZ1000 $(\mathrm{C}: \mathrm{Si}=0.9)$ is the most stable against crystallization through annealing to $1800^{\circ} \mathrm{C}$. There is, therefore, a clear evidence that the $\mathrm{C}: \mathrm{Si}$ ratio governs the crystallization of phases in SiAlCN ceramics. After heat-treatment to $1800^{\circ} \mathrm{C}$, all the samples exhibit the reflections characteristic of a $2 \mathrm{H}$ wurtzite-type compound ${ }^{70}$. The similarity in the basal plane lattice parameters between AIN and SiC suggests that AlN may seed $\mathrm{SiC}$ crystallization ${ }^{31,32}$. Interestingly, silicon nitride $\left(\mathrm{Si}_{3} \mathrm{~N}_{4}\right)$ is absent even though some XRD peaks attributed to $\mathrm{SiC}$ could be assigned to $\beta-\mathrm{Si}_{3} \mathrm{~N}_{4}$ (whereas $\mathrm{Si}_{3} \mathrm{~N}_{4}$ is identified in SiBCN ceramics). This probably means, based on $\mathrm{XRD}$, that $\mathrm{Si}_{3} \mathrm{~N}_{4}$ decomposed by the carbon leading to $\mathrm{SiC}$ according to the reaction depicted in the following equation: $\mathrm{Si}_{3} \mathrm{~N}_{4}+3 \mathrm{C} \rightarrow$ $3 \mathrm{SiC}+2 \mathrm{~N}_{2}$. This reaction usually occurs at $1484^{\circ} \mathrm{C}\left(\mathrm{P}_{\mathrm{N} 2}=1 \text { bar }\right)^{71}$.

Raman spectroscopy is an important non-destructive tool for investigating the structural evolution of the free carbon phase in these materials. Free carbon appears in the Raman spectra of PDCs in the form of disordered-induced D and D' bands at $\sim 1350$ and $1620 \mathrm{~cm}^{-1}$, 
the $\mathrm{G}$ band at $\sim 1582 \mathrm{~cm}^{-1}$ due to the band stretching of $s p^{2}$ carbon, as well as the $\mathrm{G}^{\prime}$ band that is overtone of the D band at $\sim 2700 \mathrm{~cm}^{-1}$, characteristic of defect-free samples ${ }^{72,73}$. Raman spectra of the samples annealed under $\mathrm{N}_{2}$ at $1000,1200,1400,1600$ and $1800^{\circ} \mathrm{C}$ are presented in Figure 12. The samples exhibit the characteristic broad D and G signals and strong overlaps at each temperature from 1000 to $1400^{\circ} \mathrm{C}$ as a consequence of the structural disorder of the carbon phase which indicates carbon segregation to form disordered or nanocrystalline graphitic clusters. Since line width decreases with increasing annealing temperature, structural rearrangements accompanied by a clear ordering and/or growth of the free carbon phase occur in the temperature range 1400 and $1800^{\circ} \mathrm{C}$. At $1800^{\circ} \mathrm{C}$, in the sample PMAZ1800 these bands almost disappear while new bands appear at 830 and $920 \mathrm{~cm}^{-1}$ attributed to $\beta$-SiC. The crystalline $\mathrm{SiC}$ occurs by a free carbon consuming reaction as previously discussed on the basis of XRD. Also the AlN phase appears around $650 \mathrm{~cm}^{-1}$ in the sample at $1800^{\circ} \mathrm{C}$. Moreover, we can observe in the sample PMAZ1800, all the bands characteristic of the crystalline phases (AIN, SiC) whereas it appears the less crystallized by XRD. 

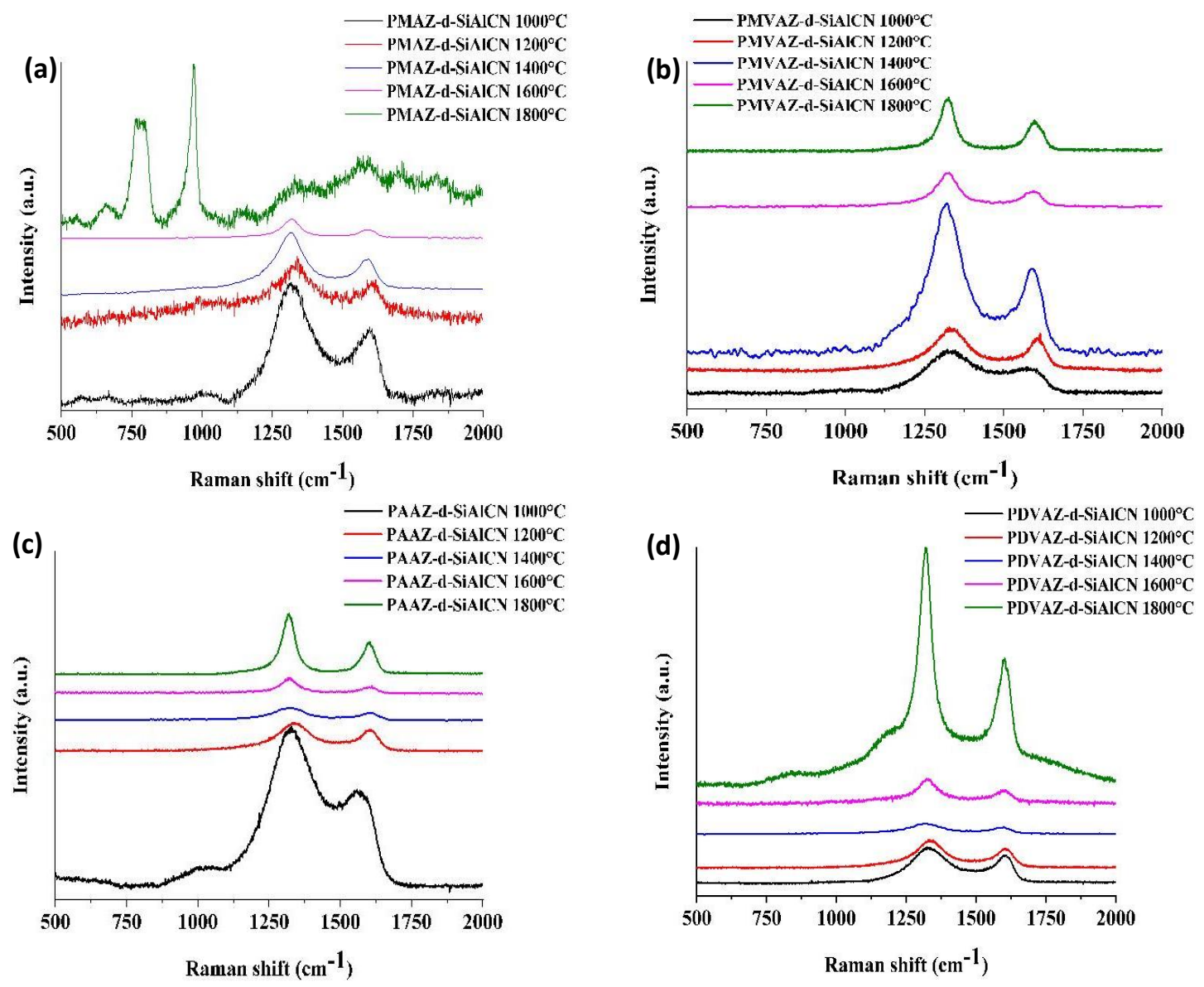

Figure 12 : Raman spectra of SiAICN materials at 1000, 1200, 1400, 1600 and $1800^{\circ} \mathrm{C}$ under $\mathrm{N}_{2}$ derived from (a) PMAZ, (b) PMVAZ, (c) PAAZ and (d) PDVAZ.

TEM studies were used to examine details of the crystallization process. Typical results obtained on the samples derived from PMVAZ at different temperatures are shown in Figures 13, 14, 15, 16). The bright field TEM image of the sample PMVAZ1000 in Figure 13-a is characterized by extended amorphous regions (predominant feature of the sample). The corresponding selected area electron diffraction (SAED) pattern supports the amorphous state of the sample. It displays diffuse haloes, indicating the amorphous microstructure of the sample heat-treated at $1000^{\circ} \mathrm{C}$. However, in some local part of the sample, fine crystallites have been observed which suggests that the sample is not a pure amorphous material (a fact that we could not presume based on XRD and Raman). The corresponding SAED (inset in Figure 13-b) is identical to $\beta-\mathrm{Si}_{3} \mathrm{~N}_{4}$. 

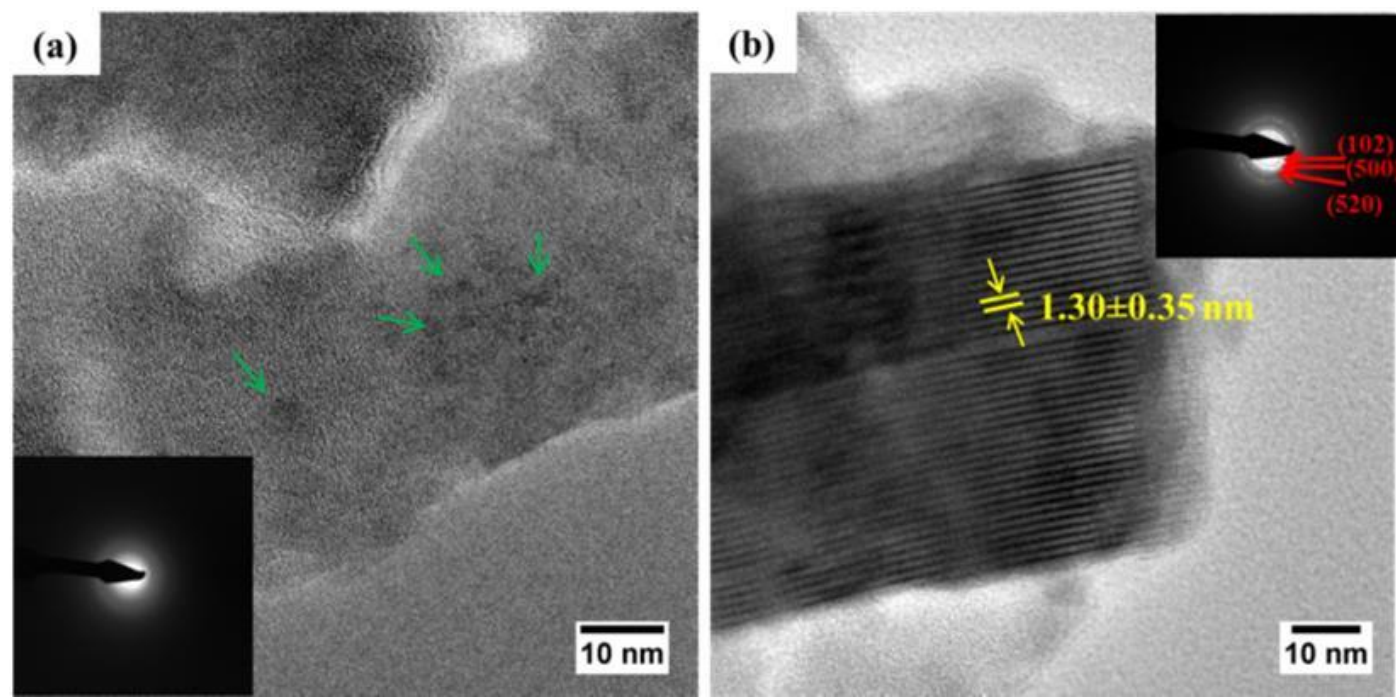

Figure 13 : TEM images of PMVAZ1000: (a) low magnification and (b) High Resolution with in inset the corresponding SAED pattern indexed with the hexagonal phase of $\beta$ $\mathrm{Si}_{3} \mathbf{N}_{4}$.

As shown in Figure 14, the TEM observation of the sample PMVAZ1400 shows a more crystallized state. This is emphasized in the SAED patterns where distinct rings and spots are clearly observed. The sample exhibits a majority of the $\beta-\mathrm{Si}_{3} \mathrm{~N}_{4}$ phase (with a $\mathrm{P} 63 / \mathrm{m}$ space group) and some $\alpha-\mathrm{Si}_{3} \mathrm{~N}_{4}$ regions as a secondary phase (Figure 14-a). No SiC-regions have been observed yet at this temperature, however, we could detect AlN nanocrystalline phases (Figure 14-b), with a $P 6_{3} m c$ space group that starts to appear at $1400^{\circ} \mathrm{C}$, as confirmed through the SAED pattern (inset Figure 14-b). The size of the AlN crystallites varies from 7 to $12 \mathrm{~nm}$ (diameters have been measured as average on long and short axis). Even though XRD and Raman spectroscopy showed that the sample was amorphous, we can conclude from the TEM spectroscopy that some crystalline phases are present in the overall amorphous matrix. 
(a)

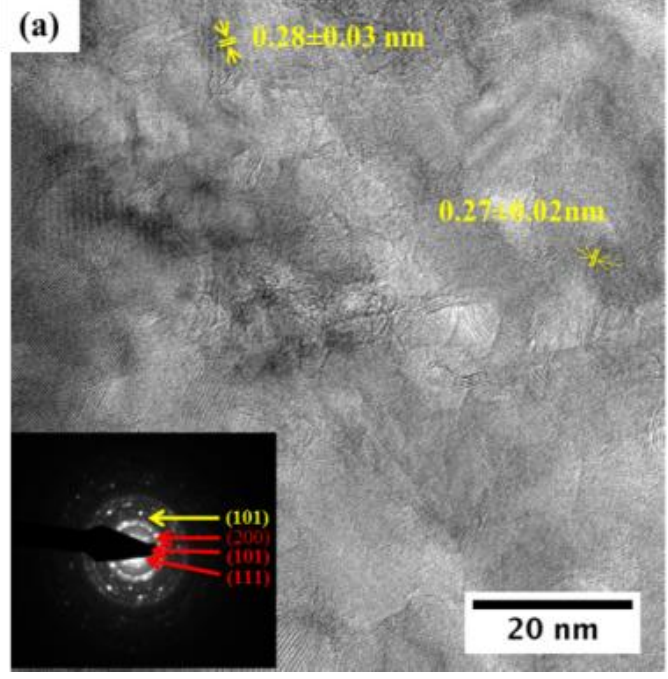

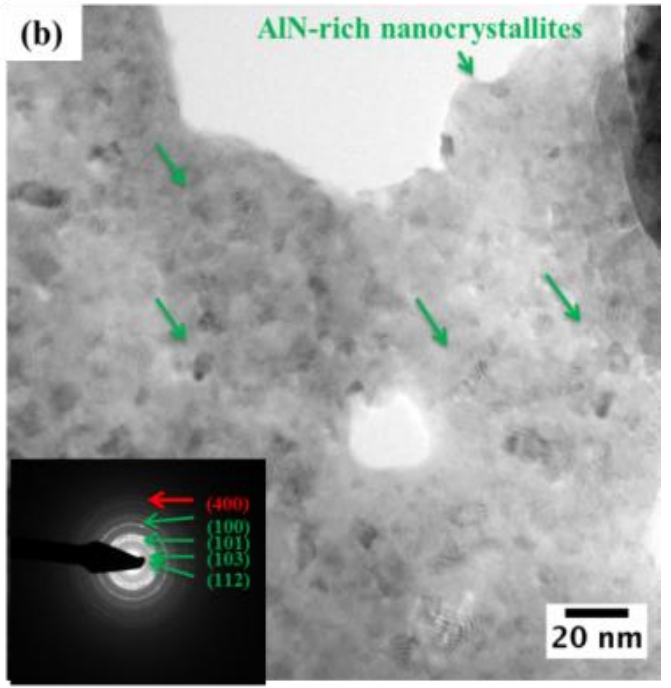

Figure 14 : TEM images of PMVAZ1400 with in inset the corresponding SAED pattern in which the red indices refer to the $\beta-S_{3} N_{4}$ phase, the green ones to the hexagonal AIN phase and the yellow ones to the $\alpha-\mathrm{Si}_{3} \mathrm{~N}_{4}$ phase.

The characterization of the sample PMVAZ1600 under nitrogen has resulted in a much more crystalline material (Figure 15). The HRTEM and SAED patterns emphasize the presence of $\beta-\mathrm{Si}_{3} \mathrm{~N}_{4}$ (Figure 15-a) and $\alpha-\mathrm{SiC}$ regions (Figure $15-\mathrm{b}$ ). The nanosized $\mathrm{SiC}$ crystallites are more frequent than the $\mathrm{Si}_{3} \mathrm{~N}_{4}$ crystallites which tend to prove that $\mathrm{SiC}$ is formed to the detriment of $\mathrm{Si}_{3} \mathrm{~N}_{4}$. $\mathrm{SiC}$ phases correspond to a space group of $\mathrm{P}_{3} m c$ that is identical to the AlN phase depicted at $1400^{\circ} \mathrm{C}$. Since we could not depict $\mathrm{AlN}$, at $1600^{\circ} \mathrm{C}$, as a single crystalline phase, we can propose that it is merged with the SiC since they crystallize in the same space group forming a solid-solution rather than a mixture of both separate phases of $\mathrm{SiC}$ and $\mathrm{AlN}$. 

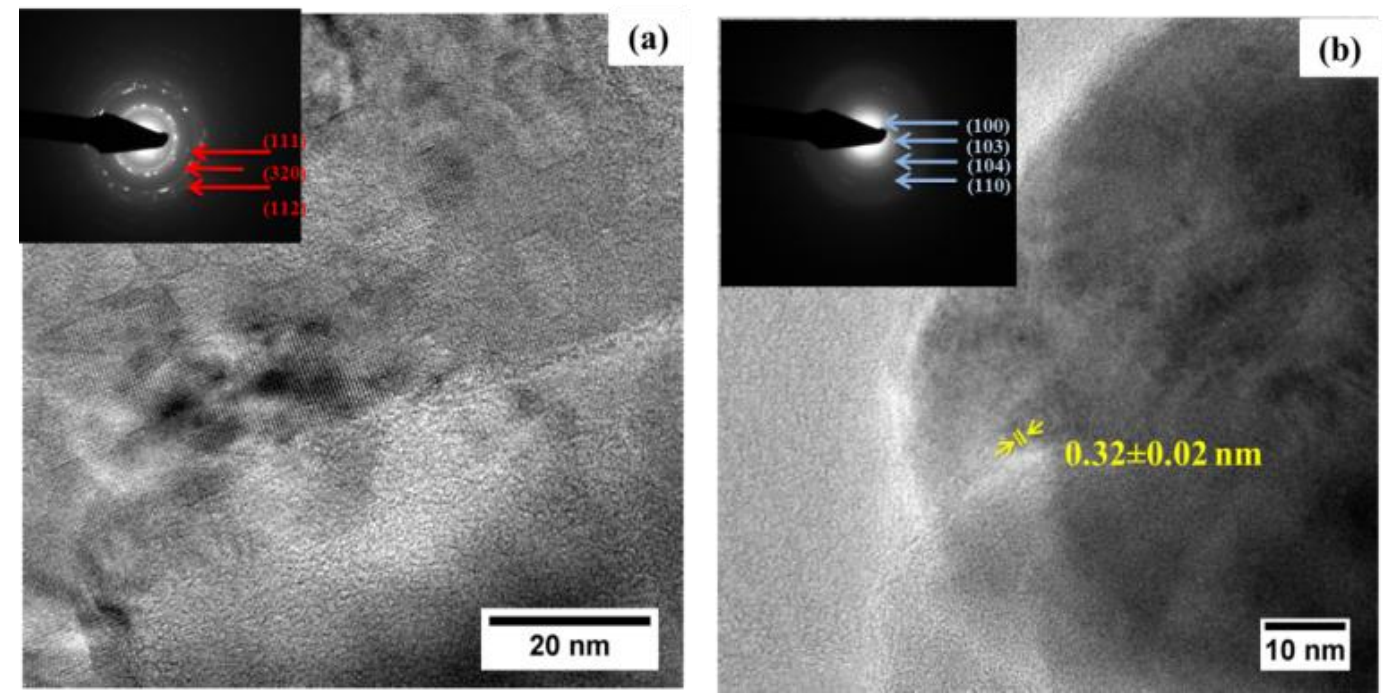

Figure 15 : TEM images of PMVAZ-d-SiAICN at $1600^{\circ} \mathrm{C}$ in $\mathrm{N}_{2}$ atmosphere.

At $1800^{\circ} \mathrm{C}$ (PMVAZ1800) a polycrystalline nature of the SiAlCN ceramic is obviously encountered with the presence of a SiC-AlN compound and SiC phases (Figure 16). Fine $\beta$ $\mathrm{Si}_{3} \mathrm{~N}_{4}$ crystallites are still present which was identified also by XRD.
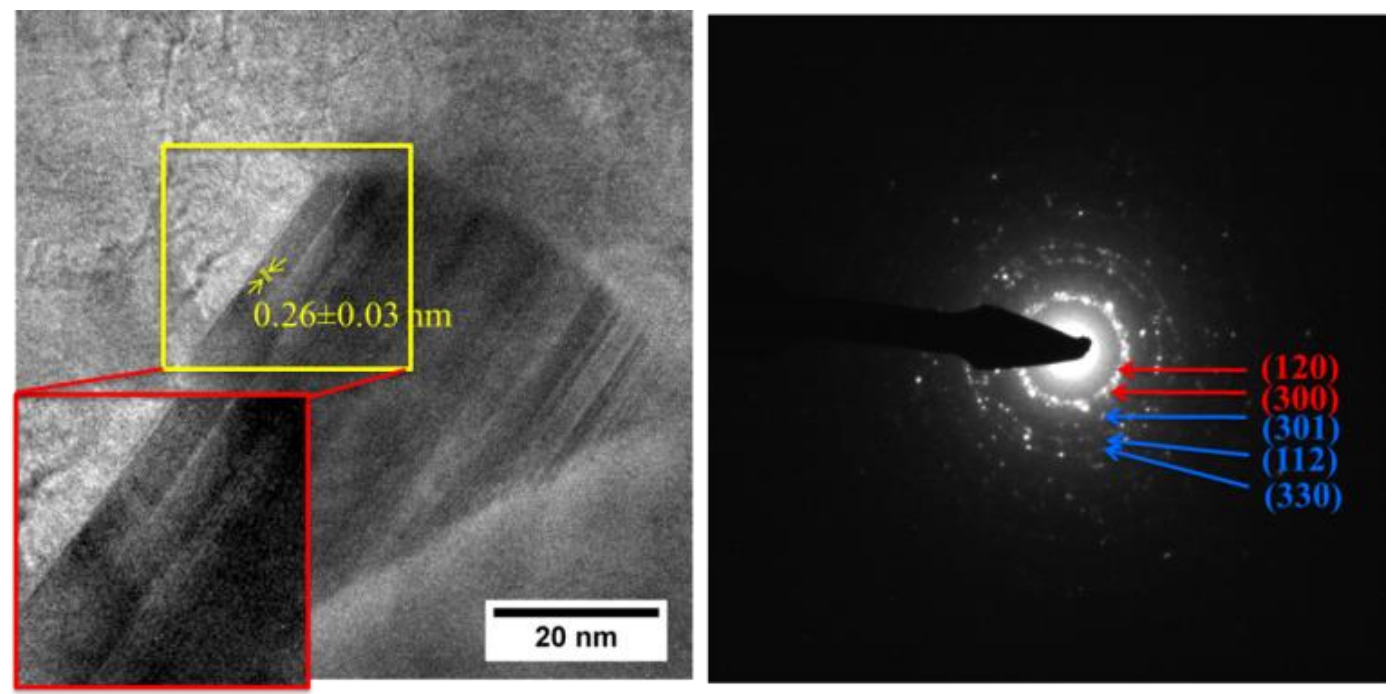

Figure 16 : TEM images of PMVAZ1800 with in inset the corresponding SAED pattern in which the red indices refer to the $\beta-\mathrm{Si}_{3} \mathrm{~N}_{4}$ phase and the blue ones to the $\mathrm{SiC}$ phase.

\section{Conclusions}

A series of silicon-aluminum-carbon-nitrogen ceramics derived from different aluminum-modified polycarbosilazanes have been synthesized and characterized. The 
preceramic polymers were obtained by the "single source precursor" approach which consists in the reaction of polycarbosilazanes with a dimethylethylamine alane complex. We prepared different types of polyaluminosilazanes starting from different types of dichlorosilanes, to compare their composition, structure, thermal behaviour and microstructure evolution with high annealing temperatures. Because of the complex structure and composition of polymers that directly affect the structure and performances of ceramics, detailed investigations of their molecular chemistry have been done. In addition, the control of the polymer-to-ceramic conversion through the design of the intermediate steps (to convert the polymer system into an inorganic intermediate) and the use of annealing treatments at different temperatures (to change the inorganic intermediate into the desired final structure) have been investigated to generate the SiAlCN ceramics. Through the use of several complementary techniques of analysis such as FTIR spectroscopy, solid-state NMR, X-ray diffraction and Raman spectroscopy, we have proposed a complete study of the structure evolution of polymer-derived SiAlCN. Alanes exhibited a different selectivity with polycarbosilazanes in comparison to borane based on former studies, for instance dehydrocoupling is in competition with hydroalumination during the reaction between alanes and polysilazanes whereas hydroboration proceeds as a major mechanism during the reaction between boranes and polycarbosilazanes. Such highly stable materials are promising materials to perform in harsh conditions. 


\section{Conflicts of interest}

There are no conflicts to declare.

\section{Acknowledgements}

The authors would like to thank the European Community FP7 through the MC-ITN FUNEA-Project which supported this work.

\section{References}

1 L.-A. Liew, Y. Liu, R. Luo, T. Cross, L. An, V. M. Bright, M. L. Dunn, J. W. Daily and R. Raj, Sensors Actuators A Phys., 2002, 95, 120-134.

2 R. Zhao, G. Shao, Y. Cao, L. An and C. Xu, Sensors Actuators A Phys., 2014, 219, 5864.

3 D. Cornu, S. Bernard, S. Duperrier, B. Toury and P. Miele, J. Eur. Ceram. Soc., 2005, 25, 111-121.

4 Z. C. Eckel, C. Zhou, J. H. Martin, A. J. Jacobsen, W. B. Carter and T. A. Schaedler, Science (80-. )., 2016, 351, 58-62.

5 J. Bill and D. Heimann, J. Eur. Ceram. Soc., 1996, 16, 1115-1120.

6 M. C. Bechelany, C. Salameh, A. Viard, L. Guichaoua, F. Rossignol, T. Chartier, S. Bernard and P. Miele, J. Eur. Ceram. Soc., 2015, 35, 1361-1374.

7 M. Schmidt, C. Durif, E. D. Acosta, C. Salameh, H. Plaisantin, P. Miele, R. Backov, R. Machado, C. Gervais and J. G. Alauzun, Chem. Eur. J., 2017, 23, 17103-17117.

$8 \quad$ P. Greil, Adv. Eng. Mater., 2000, 2, 339-348.

$9 \quad$ J. Bill and F. Aldinger, Adv. Mater., 1995, 7, 775-787.

10 R. Riedel, G. Mera, R. Hauser and A. Klonczynski, J. Ceram. Soc. Japan, 2006, 444, 33-38.

11 R. Riedel, A. Kienzle, W. Dressier, L. Ruwisch, J. Bill and F. Aldinger, Nature, 1996, 
$382,796-798$.

12 S. Bernard, C. Salameh and P. Miele, Dalt. Trans., 2016, 45, 861-873.

13 V. Salles, S. Bernard, A. Brioude, D. Cornu and P. Miele, Nanoscale, 2010, 2, $215-$ 217.

14 S. Duperrier, S. Bernard, A. Calin, C. Sigala, R. Chiriac, P. Miele and C. Balan, Macromolecules, 2007, 40, 1028-1034.

15 P. Toutois, P. Miele, S. Jacques, D. Cornu and S. Bernard, J. Am. Ceram. Soc., 2006, 89, 42-49.

16 S. Bernard, K. Ayadi, M.-P. Berthet, F. Chassagneux, D. Cornu, J.-M. Letoffe and P. Miele, J. Solid State Chem., 2004, 177, 1803-1810.

17 Z. Jiang and L. V Interrante, Chem. Mater., 1990, 2, 439-446.

18 D. Seyferth and G. Mignani, J. Mater. Sci. Lett., 1988, 7, 487-488.

19 G. Moussa, C. Salameh, A. Bruma, S. Malo, U. B. Demirci, S. Bernard and P. Miele, Inorganics, 2014, 2, 396-409.

20 C. Salameh, S. Bernard, G. Moussa, A. Bruma, G. Fantozzi, S. Malo, P. Miele and U. B. Demirci, Energy Technol., 2018, 6, 570-577.

21 C. Salameh, A. Bruma, S. Malo, U. B. Demirci, P. Miele and S. Bernard, RSC Adv., $2015, \mathbf{5}, 58943-58951$.

22 E. Ionescu, H.-J. Kleebe and R. Riedel, Chem. Soc. Rev., 2012, 41, 5032-5052.

23 M. Zaheer, C. D. Keenan, J. Hermannsdörfer, E. Roessler, G. Motz, J. Senker and R. Kempe, Chem. Mater., 2012, 24, 3952-3963.

24 G. Glatz, T. Schmalz, T. Kraus, F. Haarmann, G. Motz and R. Kempe, Chem. Eur. J., 2010, 16, 4231-4238.

25 L. Meng, X. Zhang, Y. Tang, K. Su and J. Kong, Sci. Rep., 2015, 5, 7910-7926.

26 L. David, S. Bernard, C. Gervais, P. Miele and G. Singh, J. Phys. Chem. C, 2015, 119, 
$2783-2791$.

27 M. H. Lewis and P. Barnard, J. Mater. Sci., 1980, 15, 443-448.

28 L. An, Y. Wang, L. Bharadwaj, L. Zhang, Y. Fan, D. Jiang, Y. H. Sohn, V. H. Desai, J. Kapat and L. C. Chow, Adv. Eng. Mater., 2004, 6, 337-340.

29 Y. Wang, Y. Fan, L. Zhang, W. Zhang and L. An, Scr. Mater., 2006, 55, 295-297.

30 W. Rafaniello, K. Cho and A. V Virkar, J. Mater. Sci., 1981, 16, 3479-3488.

31 R. Ruh, J. Barlowe and A. Zangvil, Am. Ceram. Soc. Bull.;(United States), 1985, 64, $1368-1373$

32 A. Zangvil and R. Ruh, J. Am. Ceram. Soc., 1988, 71, 884-890.

33 R. Ruh and A. Zangvil, J. Am. Ceram. Soc., 1982, 65, 260-265.

34 W.-C. J. Wei and R.-R. Lee, J. Mater. Sci., 1991, 26, 2930-2936.

35 J.-L. Huang and J.-M. Jih, J. Mater. Res., 1995, 10, 651-658.

36 K. W. Chew, A. Sellinger and R. M. Laine, J. Am. Ceram. Soc., 1999, 82, 857-866.

37 E. Hagen, T. Grande and M. Einarsrud, J. Am. Ceram. Soc., 2004, 87, 1200-1204.

38 C. Ma, G. Shao, J. Jiang, W. Liu, H. Wang, H. Lu, B. Fan, X. Li, R. Zhang and L. An, Ceram. Int., 2018, 0-1.

39 L. David, D. Asok and G. Singh, ACS Appl. Mater. Interfaces, 2014, 6, 16056-16064.

40 O. Majoulet, C. Salameh, M. E. Schuster, U. B. Demirci, Y. Sugahara, S. Bernard and P. Miele, 2013, 25, 3957-3970.

41 K. J. L. Paciorek, J. H. Nakahara, L. A. Hoferkamp, C. George, J. L. FlippenAnderson, R. Gilardi and W. R. Schmidt, Chem. Mater., 1991, 3, 82-87.

42 C. L. Czekaj, M. L. J. Hackney, W. J. Hurley, L. V. Interrante, G. A. Sigel, P. J. Schields and G. A. Slack, J. Am. Ceram. Soc., 1990, 73, 352-357.

43 J. F. Janik, E. N. Duesler and R. T. Paine, Inorg. Chem., 1987, 26, 4341-4345.

44 B. Boury and D. Seyferth, Appl. Organomet. Chem., 1999, 13, 431-440. 
45 A. Dhamne, W. Xu, B. G. Fookes, Y. Fan, L. Zhang, S. Burton, J. Hu, J. Ford and L. An, J. Am. Ceram. Soc., 2005, 88, 2415-2419.

46 F. Berger, M. Weinmann, F. Aldinger and K. Müller, Chem. Mater., 2004, 16, 919929.

47 D. Massiot, F. Fayon, M. Capron, I. King, S. Le Calvé, B. Alonso, J. O. Durand, B. Bujoli, Z. Gan and G. Hoatson, Magn. Reson. Chem., 2002, 40, 70-76.

48 M. Weinmann, H. Kummer, S. Prinz, J. Peng, H. Ju, M. Christ, K. Mu, J. Bill and F. Aldinger, Chem. Mater., 2000, 12, 623-632.

49 R. Riedel, J. Bill and A. Kienzle, Appl. Organomet. Chem., 1996, 10, 241-256.

50 Y. Mori, Y. Kumakura and Y. Sugahara, J. Organomet. Chem., 2006, 691, 4289-4296.

51 L. Gottardo, S. Bernard, C. Gervais, M. Weinmann and P. Miele, J. Mater. Chem., 2012, 22, 17923-17933.

52 J. Schuhmacher, F. Berger, M. Weinmann, J. Bill, F. Aldinger and K. Müller, Appl. Organomet. Chem., 2001, 15, 809-819.

53 Y. Li, E. Kroke, R. Riedel, C. Fasel, C. Gervais and F. Babonneau, Appl. Organomet. Chem., 2001, 15, 820-832.

54 J. Seitz, J. Bill, N. Egger and F. Aldinger, J. Eur. Ceram. Soc., 1996, 16, 885-891.

55 M. C. Bechelany, V. Proust, A. Lale, P. Miele, S. Malo, C. Gervais and S. Bernard, Chem. - A Eur. J., 2017, 23, 832-845.

56 L. Gottardo, S. Bernard, C. Gervais, K. Inzenhofer, G. Motz, M. Weinmann, C. Balan and P. Miele, J. Mater. Chem., 2012, 22, 7739-7750.

57 J. Lücke, J. Hacker, D. Suttor and G. Ziegler, Appl. Organomet. Chem., 1997, 11, 181194.

58 Z. Jiang, L. V. Interrante, D. Kwon, F. S. Tham and R. Kullnig, Inorg. Chem., 1992, 31, 4815-4822. 
59 J. E. Park, B. Bae, Y. Kim, J. T. Park and I.-H. Suh, Organomettalics, 1999, 3, 10591067.

60 R. Toyoda, S. Kitaoka and Y. Sugahara, J. Eur. Ceram. Soc., 2008, 28, 271-277.

61 W. S. Jung and S. A. Chae, Mater. Chem. Phys., 2010, 123, 610-613.

62 S. Schulz, T. Bauer, W. Hoffbauer, J. Schmedt auf der Günne, M. Doerr, C. M. Marian and W. Assenmacher, J. Solid State Chem., 2008, 181, 530-538.

63 A. Viard, D. Fonblanc, M. Schmidt, A. Lale, C. Salameh, A. Soleilhavoup, M. Wynn, P. Champagne, S. Cerneaux, F. Babonneau, G. Chollon, F. Rossignol, C. Gervais and S. Bernard, Chem. - A Eur. J., 2017, 23, 9076-9090.

64 C. Gervais, F. Babonneau, L. Ruwisch, R. Hauser and R. Riedel, Can. J. Chem., 2003, 81, 1359-1369.

65 D. C. Apperley, R. K. Harris, G. L. Marshall and D. P. Thompson, J. Am. Ceram. Soc., 1991, 74, 777-782.

R. K. Harris, M. J. Leach and D. P. Thompson, Chem. Mater., 1990, 2, 320-323.

67 M. Weinmann, R. Haug, J. Bill, M. De Guire and F. Aldinger, Appl. Organomet. Chem., 1998, 734, 725-734.

68 M. Monthioux and O. Delverdier, J. Eur. Ceram. Soc., 1996, 16, 721-737.

69 Y. Iwamoto, W. Völger, E. Kroke, R. Riedel, T. Saitou and K. Matsunaga, J. Am. Ceram. Soc., 2004, 84, 2170-2178.

70 I. B. Cutler, P. D. Miller, W. Rafaniello, H. K. Park, D. P. Thompson and K. H. Jack, Nature, 1978, 275, 434-435.

71 F. Aldinger, S. Frühauf, U. Herzog, B. Jäschke, T. Jäschke, E. Müller, G. Roewer, H. J. Seifert and K. Trommer, High performance non-oxide ceramics I, Springer, 2003, vol. 101.

72 A. C. Ferrari, J. C. Meyer, V. Scardaci, C. Casiraghi, M. Lazzeri, F. Mauri, S. Piscanec, 
D. Jiang, K. S. Novoselov and S. Roth, Phys. Rev. Lett., 2006, 97, 187401-187404.

73 A. C. Ferrari, Solid State Commun., 2007, 143, 47-57. 


\section{Supporting Information}

Figure $1:{ }^{27} \mathrm{Al}$ MAS NMR spectra of a) PMAZ and b) PDVAZ ( $\left.B_{0}=16.4 \mathrm{~T}, v_{\text {rot }}=20 \mathrm{kHz}\right)$.

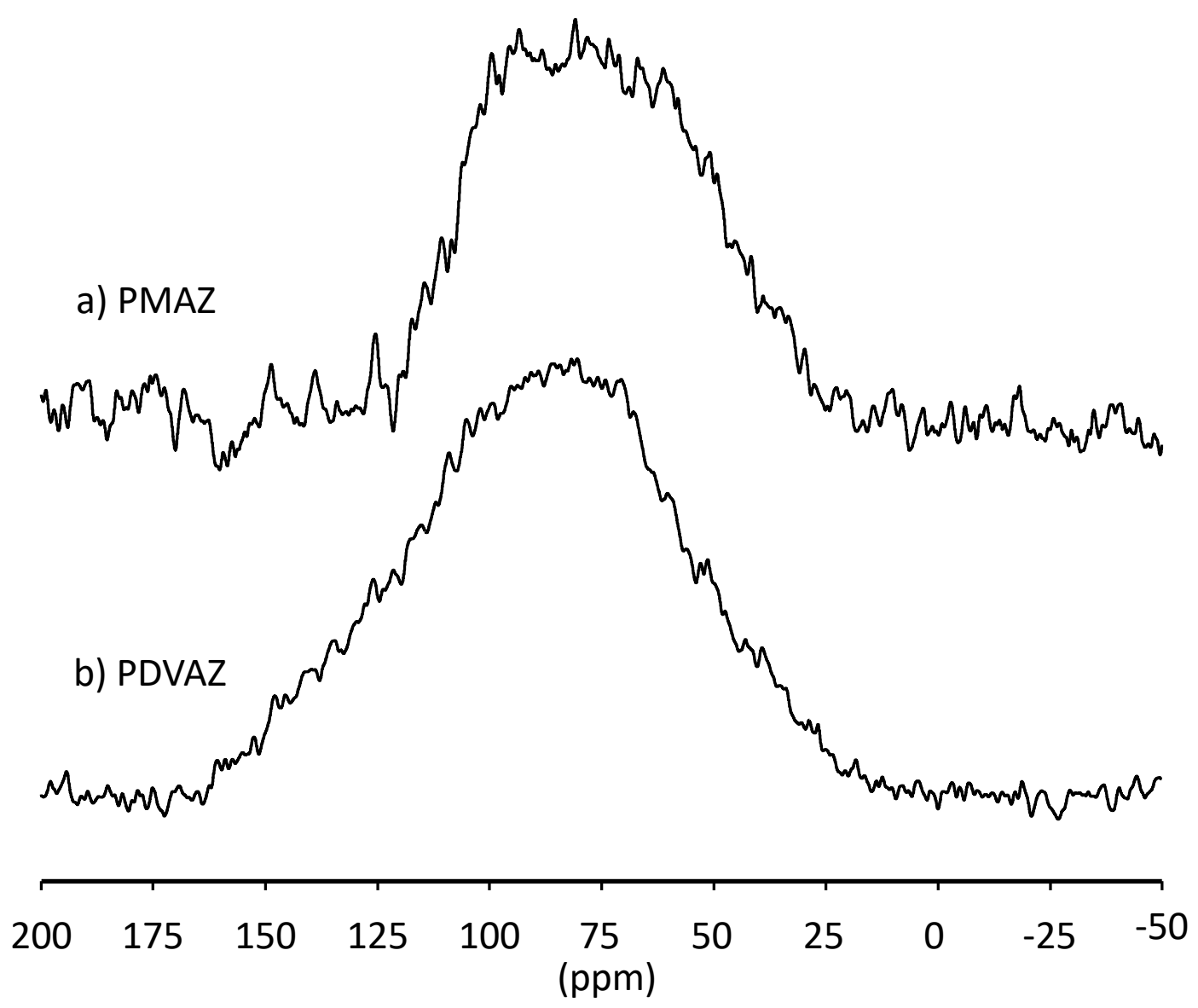

